\title{
COMPREHENSION OF RAPIDLY TRANSFORMING LANDSCAPES OF CENTRAL AND EASTERN EUROPE IN THE 20 ${ }^{\text {TH }}$ CENTURY
}

\section{RAZUMEVANJE HITRO SPREMINJAJOČIH SE POKRAJIN V SREDNJI IN VZHODNI EVROPI V 20. STOLETJU}

Mimi Urbanc

Anu Printsmann

Hannes Palang

Ewa Skowronek

Witold Woloszyn

Éva Konkoly Gyuró

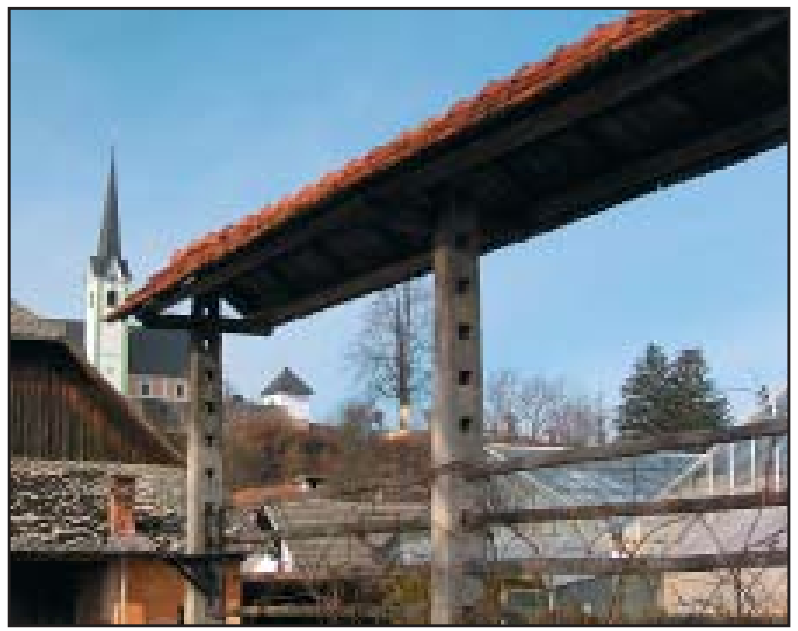

Decoding a landscape as a palimpsest, a document overwritten again and again over the passage of time enables us to comprehend a landscape as a multilayered phenomenon, integrating past and present functions, ideologies and physical contexts (photography Mimi Urbanc).

Razpoznavanje pokrajine kot palimpsest, kot dokument, sestavljen iz zapisov iz različnih obdobij omogoča razumevanje pokrajine kot slojevit pojav, ki združuje pretekle ter sedanje funkcije, ideologije in naravne danosti (fotografija Mimi Urbanc). 


\title{
Comprehension of rapidly transforming landscapes of Central and Eastern Europe in the $2^{\text {th }}$ century
}

UDC: $911.52 / .53(4-014 /-015) " 19 "$

COBISS: 1.01

\begin{abstract}
The article presents landscapes as natural, historical, cultural, social and political phenomena, and above all as a meaningful part of the environment. We will argue - by giving a contextual framework of landscape changes followed by four case studies from Central and Eastern Europe - that comprehension of landscapes has declined in the $20^{\text {th }}$ century. Along with urbanization, globalization and other societal processes rapidly varying socio-economic formations have caused alienation: changes in power result in changes in a society's values and thus some landscape elements are disintegrating, fading or disappearing and, as a result, these landscapes are taking on new, altered or modified appearances, functions and meanings. Every change in landscape needs some time to become accepted but if this re-coding of what is regarded as valuable is constantly changing, people become confused, with resultant physical consequences: land abandonment; illegal dumping; ill fitting infrastructures; inappropriate housing developments; etc. The main question is whether modern development, e. g. tourism, enhances the relationship between people and the landscape.
\end{abstract}

KEYWORDS: Central and Eastern Europe, landscape changes, landscape perception, alienation from landscapes.

The editorial ship received this paper for publishing in November $15^{\text {th }} 2004$.

\section{Razumevanje hitro spreminjajočih se pokrajin v Srednji in Vzhodni Evropi}

\section{v 20. stoletju}

UDK: 911.52/.53(4-014/-015)"19"

COBISS: 1.01

IZVLEČEK: Članek prikazuje pokrajine kot naravni, zgodovinski, družbeni in kulturni pojav, predvsem pa kot pomemben del človekovega okolja. Teoretičnemu delu, kjer predstavljamo pokrajinske spremembe, sledijo štirje primeri iz Srednje in Vzhodne Evrope, s katerimi dokazujemo, da je dojemanje pokrajin v 20. stoletju nazadovalo. Skupaj z urbanizacijo, globalizacijo in drugimi družbenimi procesi so hitro spreminjajoče se družbenoekonomske ureditve povzročile pretrganje vezi med človekom in pokrajino: menjave oblasti vplivajo na predrugačenje družbenih vrednot in zato se pokrajinske prvine razkrajajo, slabijo ali izginjajo, pokrajine pa posledično dobivajo novo ali le drugačno, preoblikovano podobo, vlogo in pomen. Vsaka sprememba v pokrajini zahteva svoj čas, da se umesti, vendar neprestano spreminjanje meril, kaj je vredno in cenjeno, bega ljudi in ima otipljive posledice: depopulacijo, opuščanje dejavnosti, divja odlagališča smeti, neustrezno infrastrukturo, regionalno neskladen arhitekturni razvoj itd. Zastavlja se vprašanje, ali sodoben razvoj, turizma na primer, izboljšuje odnos ljudi do pokrajine.

KLJUČNE BESEDE: Srednja in Vzhodna Evropa, pokrajina, pokrajinske spremembe, dojemanje pokrajine, odtujitev.

Prispevek je prispel v uredništvo 15. novembra 2004. 


\section{Contents}

$1 \quad$ Introduction 104

2 Landscape change: time and alienation 105

3 Four case studies 107

3.1 The Setu case (Estonia) 107

3.2 The Fertó-Hanság case (Hungary) 110

3.3 The Roztocze case (Poland) 114

3.4 The Kras Case (Slovenia) 115

4 Discussion: how to overcome people's alienation from landscapes 118

5 Conclusion 120

6 References 120

\section{Vsebina}

$1 \quad$ Uvod

2 Pokrajinske spremembe: čas in odtujitev

3 Štiri testna območja

3.1 Setu (Estonija)

3.2 Fertó-Hanság (Madžarska)

3.3 Roztocze (Poljska)

3.4 Kras (Slovenija)

4 Diskusija: kako preseči odtujitev ljudi od pokrajine

6 Literatura

ADDRESSES - NASLOVI:

Mimi Urbanc, M. Sc.

Anton Melik Geographical Institute

SRC SASA, Ljubljana, Slovenia

E-mail:mimi@zrc-sazu.si

Anu Printsmann, M. Sc.

Institute of Geography, University of Tartu, Estonia

E-mail: anu.printsmann@ut.ee

Hannes Palang, Ph. D.

Institute of Ecology, Tallinn Pedagogical University, Estonia

E-mail: palang@eco.edu.ee
Ewa Skowronek, Ph. D.

Marie Curie Sklodowska, University Lublin, Poland E-mail: eskowron@biotop.umcs.lublin.pl

Witold Woloszyn, Ph. D.

Marie Curie Sklodowska, University Lublin, Poland E-mail:WITWOL@biotop.umcs.lublin.pl

Éva Konkoly Gyuró, Ph. D.

University of Western Hungary, Sopron, Hungary E-mail: egyuro@emk.nyme.hu 


\section{Introduction}

This paper explores the mechanisms of understanding of landscapes in Central and Eastern Europe and their consequences. Understanding of landscapes' elements and processes helps to secure a better quality of living environment which is the aim of the European Landscape Convention (Internet). We believe that landscapes in Central and Eastern Europe are understood differently from the rest of the Europe which has enjoyed more stable development during the $20^{\text {th }}$ century in terms of socio-economic formations. We see rapid transformations of socio-economic formations as the key factor of understanding landscape changes in Central and Eastern Europe. However, although sharing similar traits in formation history, the region should not be regarded as homogeneous because differences in historico-political conditions have resulted in different perceptions of, and coping strategies for, landscape changes which have occasioned differing future developments.

In scientific use there have been several methods employed to define landscape (see, e. g. Antrop 2000; Claval 2004; Jones 2003; Keisteri 1990; Olwig 2002; Palang and Fry 2003; Sauer 1925). Based on the western world's stability Lowenthal (1997) lists three reasons for considering a landscape as patrimony. First, landscapes are material, as they are perceived with all our senses, which make them tangible. Second, landscapes are used as containers for a large variety of artefacts which gives them a broader context and hence enhances their individual values. Finally, landscapes are the most fixed, immovable phenomena in our environment. This quality makes landscape feel secure and reliable. While a humanistic approach (e.g. Relph 1986; Robertson and Richards 2003; Tuan 2003) prevailed in Anglo-American cultural geography in the second half of the $20^{\text {th }}$ century, most of the Central and Eastern Europe landscape science was affected by the German-Russian school concentrating more on physical landscapes than on understandings of landscape by people (Harteisen 2000; Perko and Orožen Adamič 1998). This changed considerably after the downfall of communism as local groups and communities with their customs and traditions assumed a more significant role in shaping their own environment on ethical and on practical grounds (Mikesell 2000).

In this respect it is important to know how landscapes are understood in everyday use (see Table 1), as landscapes are a medium through which the link between humans and nature is created.

Table 1. The meaning of landscape in everyday use in some Central and Eastern European languages.

\begin{tabular}{|c|c|}
\hline Estonian maastik & $\begin{array}{l}\text { "Maa« means land, earth and country, suffix »-stik« indicates that it is a modern word, originating from the } \\
\text { beginning of the } 20^{\text {th }} \text { century. The term came into usage through literature and paintings. } \\
\text { 1. It signifies a territory, abstract (hierarchical) as well as of a concrete size (the hilly South-Estonian } \sim S \text { ). } \\
\text { 2. can also be a typical part of territory (coastal } \sim \text { ). } \\
\text { 3. } \sim \text { s as a visual expression and appearance of the surrounding (forested } \sim \text { ). } \\
\text { 4. Lately there has been a shift in meaning and now we are talking metaphorically about political, } \sim S \text { music } \sim S \text { etc. }\end{array}$ \\
\hline Hungarian tàj & $\begin{array}{l}\text { 1. Territory (not very large) where geographical factors and vegetation etc. are uniform or coherent } \\
\text { ( of the Danube, hilly }(\sim) . \text { The visible nature around us (winter } \sim) \text {. }\end{array}$ \\
\hline & 2. Environs, countryside (in the environ of someone's house). \\
\hline Polish krajobraz & $\begin{array}{l}\text { »Kraj« means country and »obraz « signifies picture, view, so »krajobraz« can be directly translated as a 'picture } \\
\text { of the country'. - in popular understanding means: view, picture or scenery of close surroundings } \\
\text { (neighbourhood); physiognomy of the Earth surface. }\end{array}$ \\
\hline Slovenian pokrájina & $\begin{array}{l}\text { 1. Smaller or bigger territory defined by shaping, overgrowing, settling; mountainous } \sim \text {, tropical } \sim \text {; defined } \\
\text { smaller or bigger territory; Dolenjska; historical } \sim \text { s (in the sense of a province). } \\
\text { 2. An art painting presenting a } \sim \text {. } \\
\text { 3. Literary: interesting mental } \sim \text { s; juridical: Socialist autonomous } \sim \text { of Kosovo; ecclesiastic: church } \sim \text {; cultivated } \sim \text {. }\end{array}$ \\
\hline
\end{tabular}

In everyday use a landscape is very often understood as a picture, scenery, or appearance of the terrain. The focus seems to be clearly on nature, i. e. landscape is understood primarily as a natural phenomenon, or at least this is what has been taught to people in school. However, on investigation, cultural issues are revealed as being important - but are considered less significant because of the subjective and personal nature of these notions. These notions were not important during communist times, compared with scientific paradigms. Also, there seems to be no notion of time and its social, economic or political con- 
ditions in the everyday use of the term. Apparently, the rapid social and economic changes in the landscapes themselves have not been recognized yet in everyday language. Language reflecting nature-related words seems to be inertial, as we are used to treating the physical environment as something stable, which it is not. Our attitudes, whether nature is something powerful with which to co-exist harmoniously, to tame or to protect, change along with socio-economic conditions.

\section{Landscape change: time and alienation}

Cosgrove (1984) has described how every socio-economic formation tries to create its own landscape by wiping off the uses and symbolic values of previous formations and replacing them with its own. A formation should here be understood as a set of political, economic, social, cultural and also ecological conditions prevailing in a society. In Western Europe, the change from one formation to another has been gradual, and transitions took decades, if not centuries. Also, each formation has had time to develop its own landscapes. Through the arts and communication, a landscape ideal (representation) is created, and that later becomes the yardstick for policy and tourism (Vos and Meekes 1999). It contains memories of the past (so vividly described by Schama 1995) and preconditions for the future.

Central and Eastern European countries have witnessed, experienced and practiced a set of socio-economic formations in the $20^{\text {th }}$ century that caused profound and widespread changes in the landscape's forms, meanings and perception, resulting in layered landscapes. We can speak of imperial landscapes created prior to 1918, which were followed by the emergence of national states, the increase of nationalist sentiment in Estonia, Poland and Slovenia and a sense of loss and grief in Hungary due to the territory lost after World War I. The post-World War II eras brought forth socialist values, scenery, practices, ecology and representations. The 1990s brought along another change with a turning towards the West, a rapid decline of agricultural practices, and a new recoding of the meaning of the landscapes. We argue that the rapid transformations of socio-economic formations cause alienation from the landscape which has gone as far as it can go, with the lack of traditional landscape identity exacerbating environmental problems.

In postmodernity some of the landscape elements of the previous formations are eradicated but some artefacts and mentifacts remain and remind us of the complex history although their functions and mean-

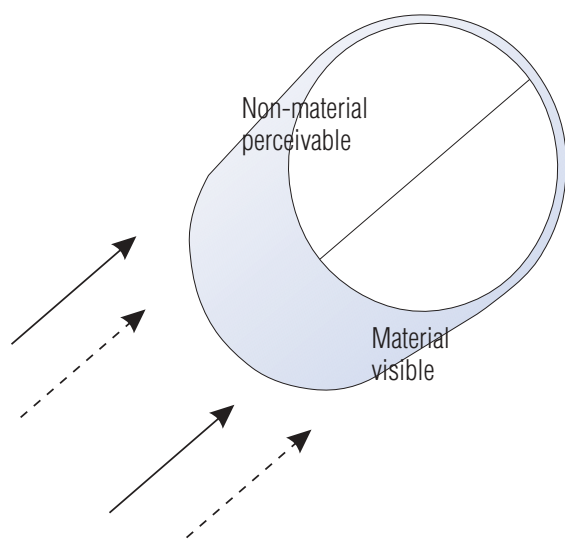

Underlying processes 
ings may have changed. For better understanding of the changes we need to clarify the interface (Palang and Fry 2003) between the mental and material spheres and their underlying factors (Figure 1) in landscape during the time. Appleton (1996) has shown that human behaviour that changes the landscape is not influenced by environment directly, but through a person's attitude towards the environment, not as it is, but as he thinks it is. In other words, the image of an environment is what counts, and this image may be distorted in all sorts of ways.

The main distorter of the image of an environment is the ideology of the prevailing socio-economic formation structure. Lefebvre's (1991) notion of spatial practice (also called social spatiality by Simonsen, 1996) which is a dialectical interaction between society and its environment combines within it representations of space and spaces of representations. Representations of space are formed by ideology; it is a conceptualized space (also a conceived space), where locales for actions are pre-given and these (locales and actions) may differ from one formation to another. A space of representations is an environment where objects have meanings (a lived space). Representation of space is like a container of all possible relevant meanings determined by ideology and thus, unless many landscape elements are assigned new values, they tend to disappear. Alienation arises from the gap between the nexus of pre-existing objects which have changed their meaning, and new objects which bear meanings symbolic of a new formation.

No ideology of socio-economic formation sets out to cause alienation, but it is the side-effect of their frequent changes. Bourassa (1991) has described three levels of landscape experience: biological laws, cultural rules and personal strategies. Alienation is prescribed by evolution; we cannot expect that our children will value the same things as we do, and thus generational conflict is universal (Kohli 1996). A second level of alienation (cultural) can be brought about artificially through social representations, ascription of new meanings to old elements in the media, and conflict between official ideology and traditional lifestyles. This is found in all of our case studies. A third level of alienation (individual) occurs when people are separated from the land by the ruling power, local inhabitants leave or are forced to leave home, and outsiders immigrate.

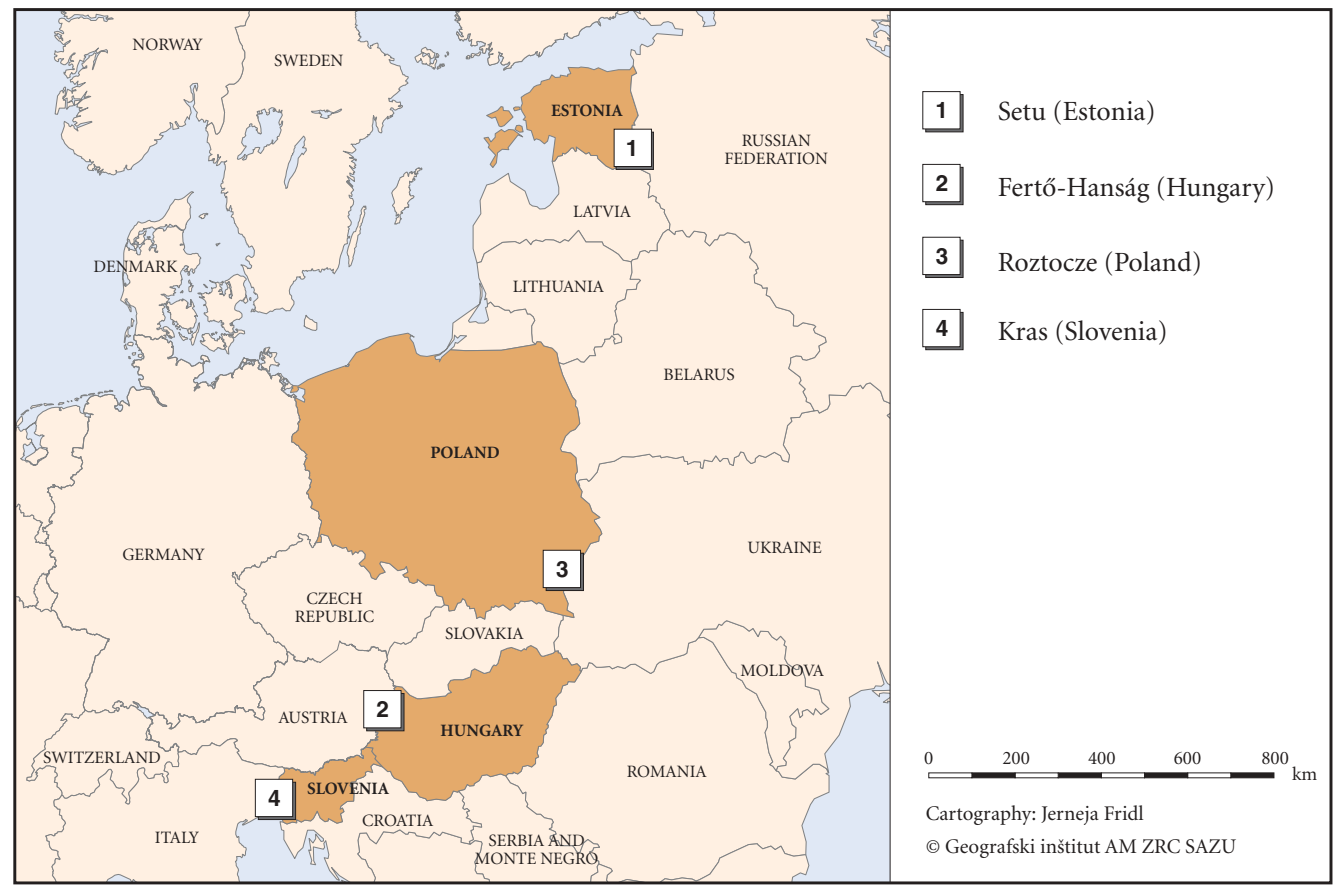

Figure 2: Location of case study areas. 
Four case studies from Estonia, Hungary, Poland and Slovenia (Figure 2) are used to show transformations of land use, ecological conditions, meanings and symbolic values in landscapes resulting from socio-economic changes. These case studies show that over-frequent recoding of landscapes causes alienation between people and landscapes triggering unplanned landscape changes which are exacerbated by other socio-economic processes, such as urbanization and industrialization.

\section{Four case studies}

\subsection{The Setu case ${ }^{1}$ (Estonia)}

Setu is a region which once belonged to Russia and Estonia and today is again divided between the two. It is situated between the eastern and western churches and between the Slavic and Fenno-Ugric tribes. Its location on the borders of those countries has resulted in the retention of traditional cultural characteristics. In the $19^{\text {th }}$ century the Setus still had communal ownership of land, which was a barrier to individual initiative and economic development. Setu was left unaffected by national romanticism due to the illiteracy of the people. After reuniting with Estonia (1920) Setu culture started to become more similar to other Estonian cultures. Enduring Russian influences can be observed in its culture - the Russian Orthodox religion, buildings, traditional clothes, folk dances, celebratory customs, folk tales etc. Due to religious and cultural separation some old Southern Estonian elements are well preserved. The Setus are not Russians; most often they are treated as Estonians who have an alternative culture.

\subsubsection{Republic of Estonia (1918-1940)}

Social and cultural life adapted to the Estonian models of organization; schools became Estonian-speaking. In church the main inclination was towards priests who could understand the Estonian or Setu languages. The Russian Orthodox religion was one of the cultural components that shaped the thinking (Estonians are Lutherans) during that time, although it was intertwined with pagan beliefs. There remained a 'holy' or 'God's corner' in every living room where icons or holy statues were kept (Ränk 1957). Pagan customs were explained by lack of education but also by an awareness of self and a reluctance to accept anything new as their own culture was seen as very fragile. Alcohol was recognised as a problem even then. Outbreaks of violence at village social events were thought to be caused by alcohol and also by the fact that the ethnic group was in the process of losing its sense of identity and cultural coherence (Põldmäe 1938).

During the independence period of the Republic of Estonia Setu culture developed but, turning more towards the Estonian traditions, it became more distant from Russian culture. Traditional Setu customs were preserved but their significance was somewhat diminished. Land use reform brought some economic independence also.

Estonians saw the Setus as lower class, although intellectuals considered them important because of their potential to cast some light on the Finno-Ugric past. The official attitude was to "win them back « for the Estonian side.

\subsubsection{The Soviet period (1945-1991)}

In 1945 part of the Setu region was incorporated into the SFSR as an ethnical border was difficult to draw because of the intertwined settlements of the Setus and Russians. The border - the majority of Estonian territory was organised as the Estonian SSR - was administrative and did not end cross-border movement, yet Setu villages on the Russian side started to be abandoned (Jääts 1998). Collectivization and forming of kolkhozes and sovkhozes took place 1947-1951. During the 1980s a so-called »shadow «-economy prospered. Every family had its own cucumber or onion fields; products were sold in Pskov and Leningrad (now St. Petersburg) (Jääts 1998).

\footnotetext{
${ }^{1}$ This case study has been written together with Kadri Semm.
} 


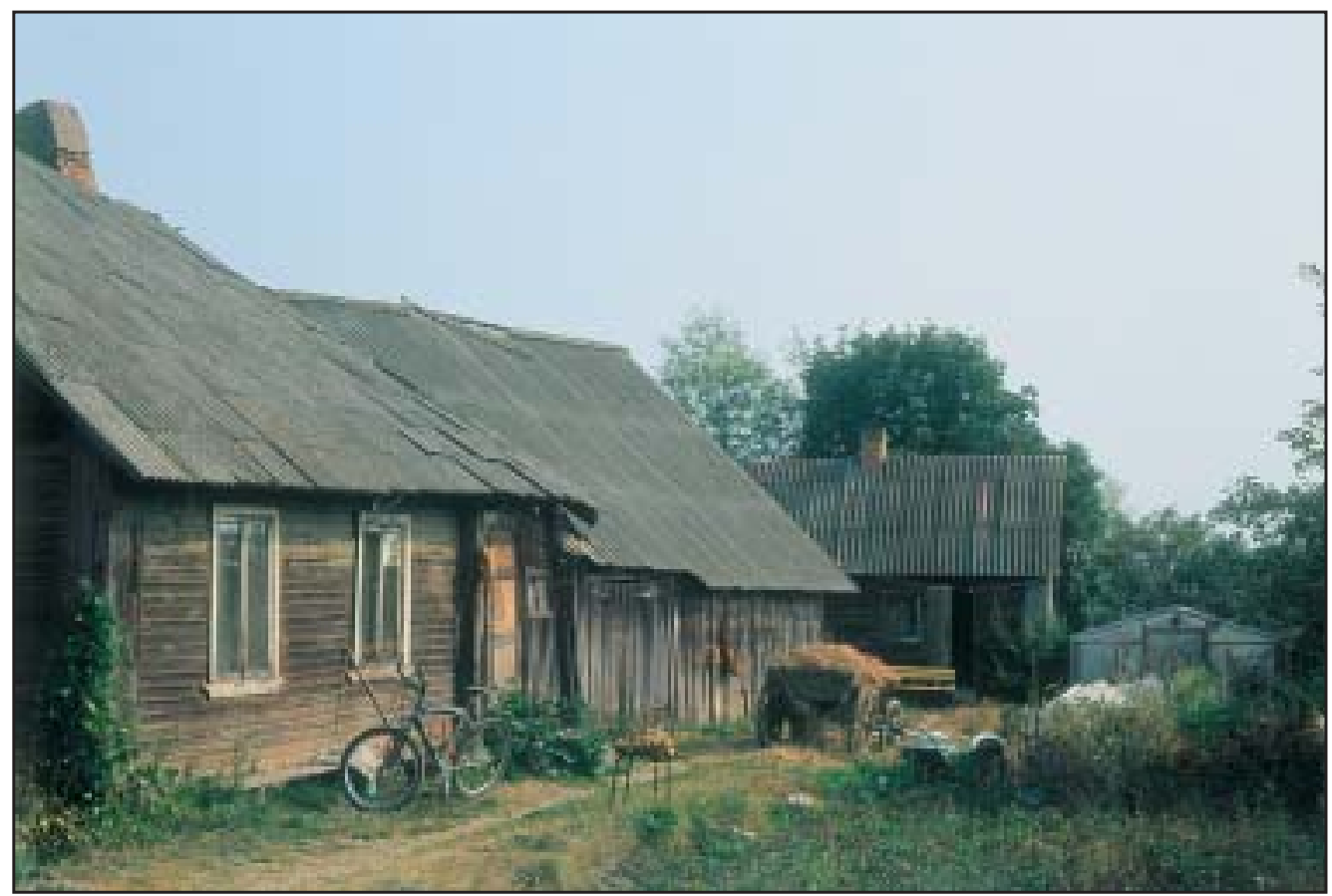

Figure 3: A typical Setu farm situated around a rectangular courtyard. Despite the fact that most of the buildings are run down, the exteriors still remind Estonians of the golden era of private farming in the 1930s (photography Mimi Urbanc).

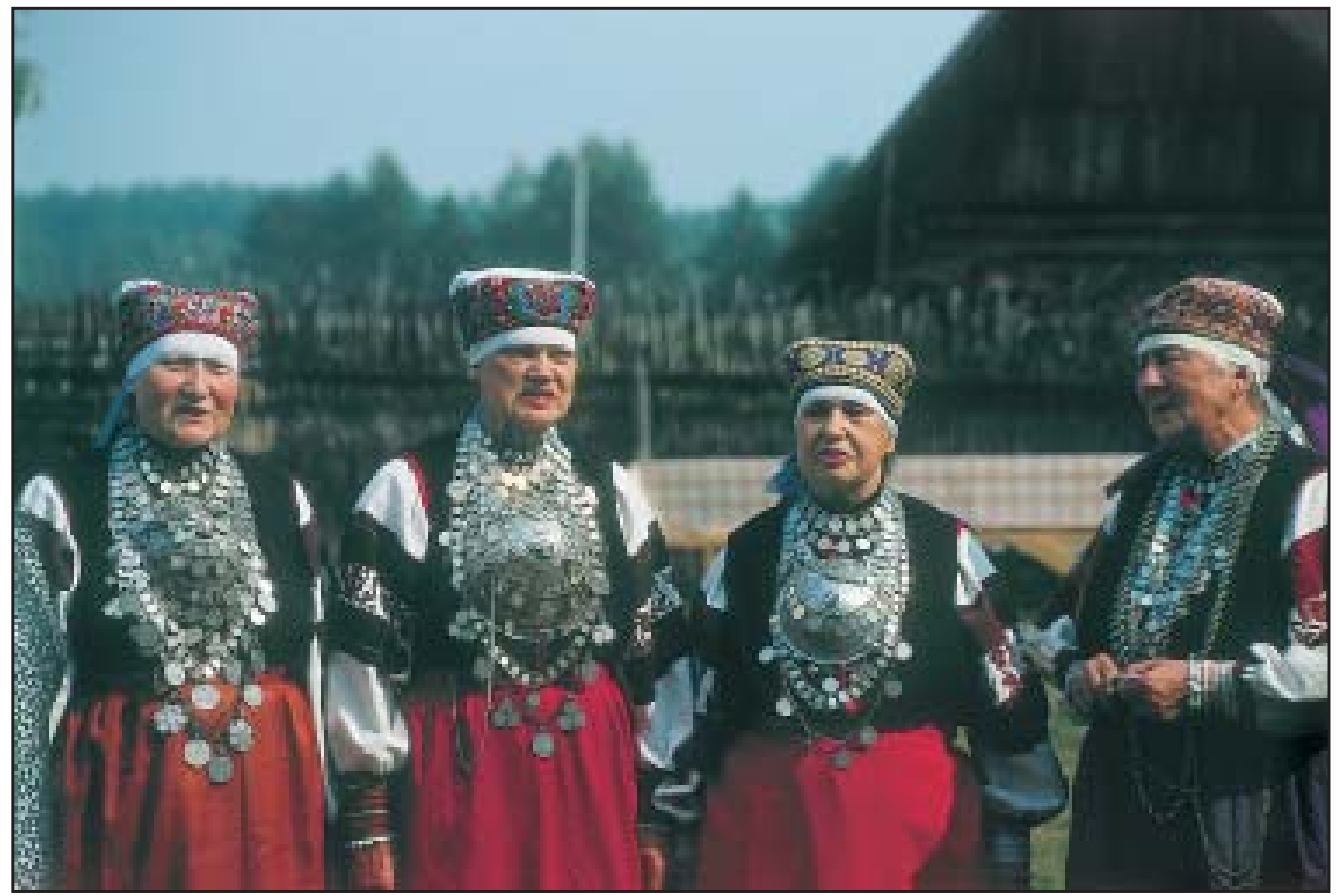

Figure 4: Setu woman in traditional festive folk costumes. Setu choirs are famous for multi-voice singing (photography Mimi Urbanc). 


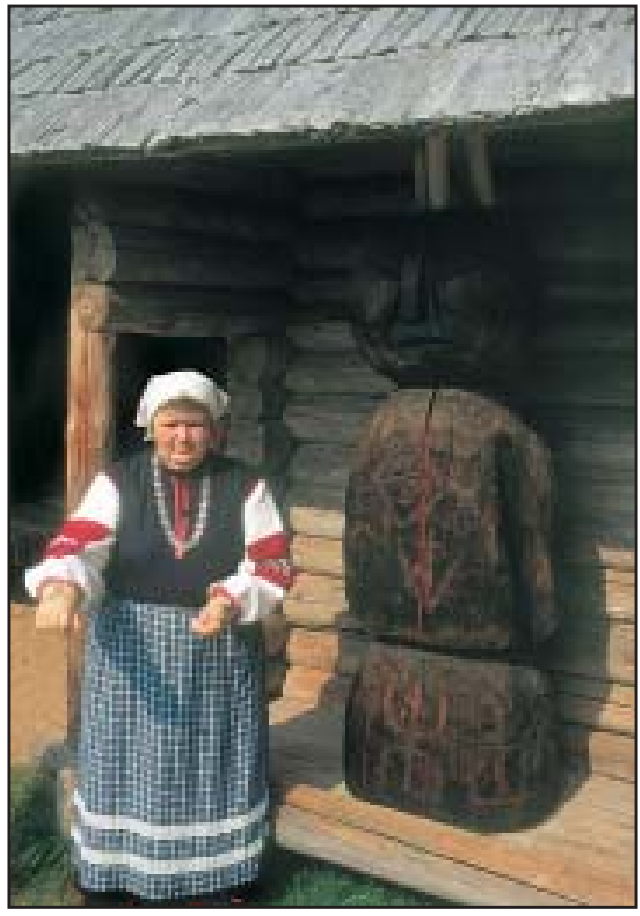

Figure 5: Re-discovering roots. A replica carved figure of a pagan fertility god is placed next to the front door; it also serves as a tourist attraction (photography Mimi Urbanc).

The school system supported the written Estonian language and the idea that religion belonged to the past. Despite this, in the early 1950s churches in Obinitsa and Meeksi were built, partly under cover of darkness, and young people at the same time demolished small chapels. The older generation lived according to traditional beliefs but youngsters abandoned the old ways as they did not want to be seen as old-fashioned. They also concealed their origin as Setus who were considered second class citizens based on religion and cultural traditions (Valk 1996). Literature described Setu as a tourist region with beautiful nature and completely ignored its cultural heritage. New and powerful symbols arose: the mineral water and sanatorium of Värska became more valued than the national characteristics of the Fenno-Ugric peoples.

\subsubsection{Republic of Estonia (after 1991)}

The district of Setu is on Estonia's periphery and is marked by rural decline (Jääts 1998). The older generation still keeps the old customs alive (e.g. not working on Sundays, eating in graveyards, fasting) and villages uphold Russian Orthodoxy (Valk 1996). Although the younger generation has rejected the old values, some still acknowledge the traditional customs. The border between Estonia and Russia has become a serious barrier to movement (e. g. graveyards are situated on the other side). Interestingly, this barrier is also a symbol of unity for the Setu people and gives them a sense of identity and political awareness. This new sense of identity coincided with the political changes at the end of the 1980s. Among locals the Soviet period is perceived as a destruction of their identity. Things valued during that period (e. g. collective farms, apartment houses) are being seen now as irrelevant. The amount of literature about the old customs of the Setu district is growing, promoting the sustainability and continuance of traditions as something to be taken for granted. What was formerly considered as poverty is seen now as a means of saving old traditions which attract tourism and hence income. 


\subsection{The Fertö-Hanság case (Hungary)}

The Fertó-Hanság basin, lowland encircled by hills, lying on the NW border of Hungary occupies some $60 \mathrm{~km}^{2}$. These landscapes once comprised a connected lake and marshland and inhabitants therefore learned to live with and from its waters. During the $18-19^{\text {th }}$ century, Hungary was predestined by natural conditions to be the main food producer of the Habsburg Empire. In the second half of the $19^{\text {th }}$ century the growing population, the emancipation of the serfs and the enlarged market within the Monarchy provoked an increasing and more intensive agricultural production along with extensive river regulation and reclamation of marshland; the dried-out marshlands and grasses were rapidly turned into arable land. Nevertheless the drawbacks of the reclamations became evident. The dry, peaty soil needed a water supply, and thus an irrigation system was constructed which together with new roads led to a totally transformed, "modern « landscape structure in the lowlands. On the other hand on the hilly borderland of Lake Ferto" the land-use structure remained intact (Konkolyné Gyuró 2003).

\subsubsection{Between the two World Wars}

After WW1 2/3 of the former territory of Hungary was annexed, $87 \%$ of the forests, and $85 \%$ of the grasslands became territories of neighbouring countries. The country had difficulty in coming to terms with this immense loss. Land use systems and territorial co-operation of work collapsed. The most evident shortage was that of wood. The large-scaled national reforestations program fell through or had to slow down considerably because of the worldwide economic depression and the ensuing world war. The situation was similar in the case study area, although new tree plantations were carried out in the former marshland, the proportion of arable land also increased, but only slightly, and consequently only a small part the original habitat structure of the Hanság survived the human transformation (Konkolyné Gyuró 2000). Population continued to grow. It was then that recreation became popular on the shores of Lake Fertó, thus exploiting natural resources. Recreation sites were built; the shallow, pleasantly warm water attracted the inhabitants of Sopron and Vienna. In addition, a sulphuric medicinal spring was found on the Hungarian side, on which the dynamically developing present-day thermal baths are built.

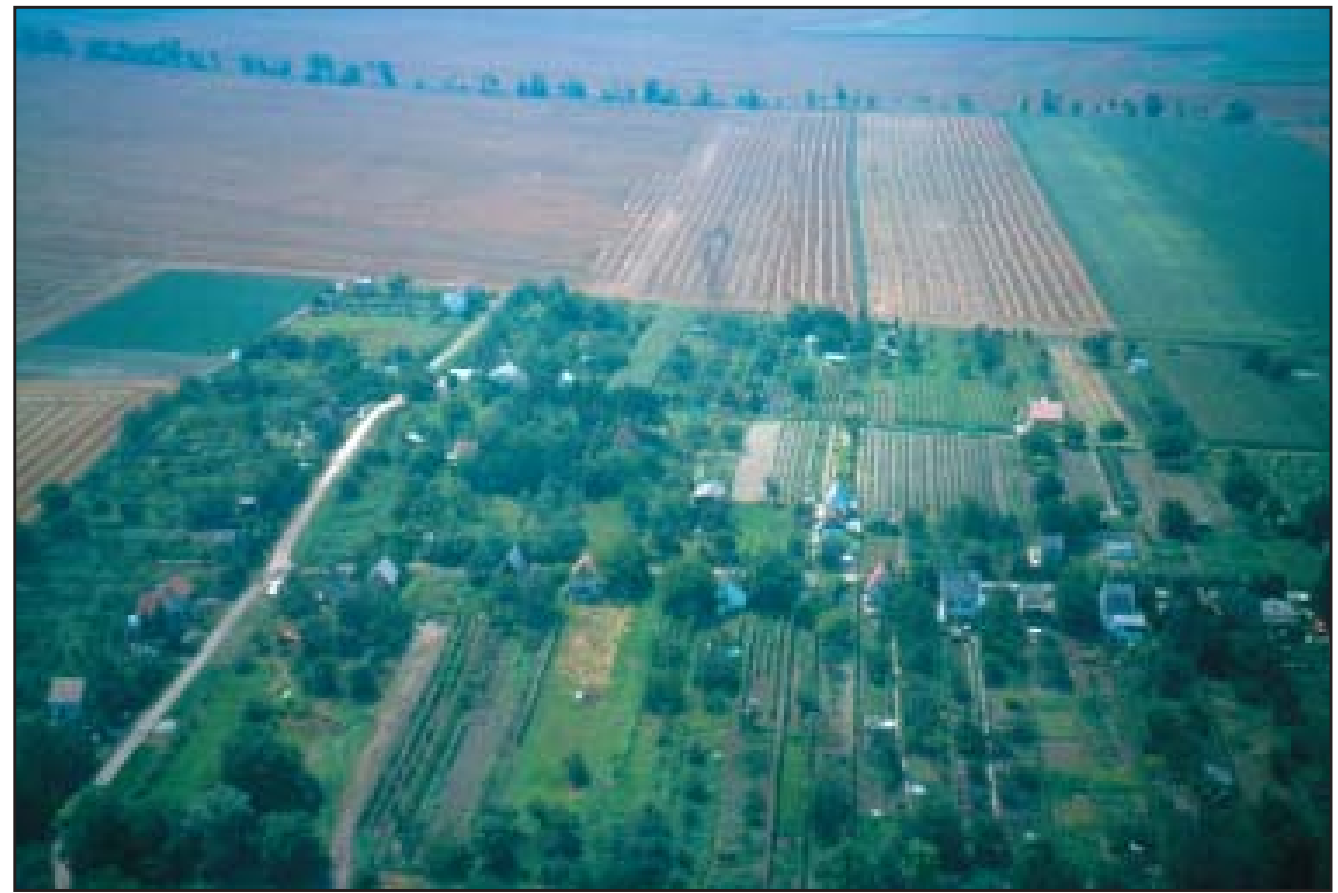

Figure 6: The new landscape of the Hanság after the Second World War (photography Éva Konkoly Gyuró). 


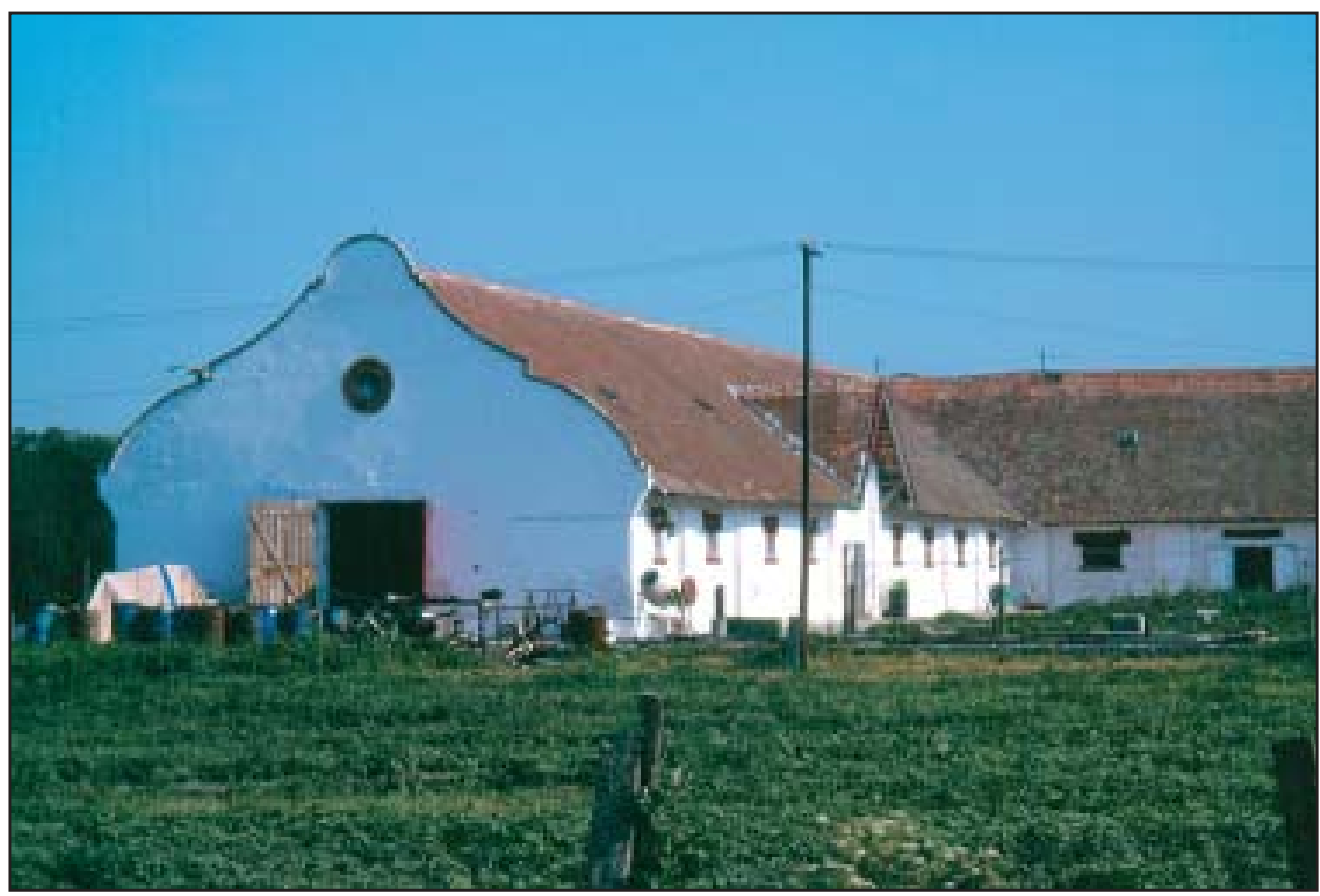

Figure 7: Remains of the cultural heritage of the Hanság (photography Éva Konkoly Gyuró).

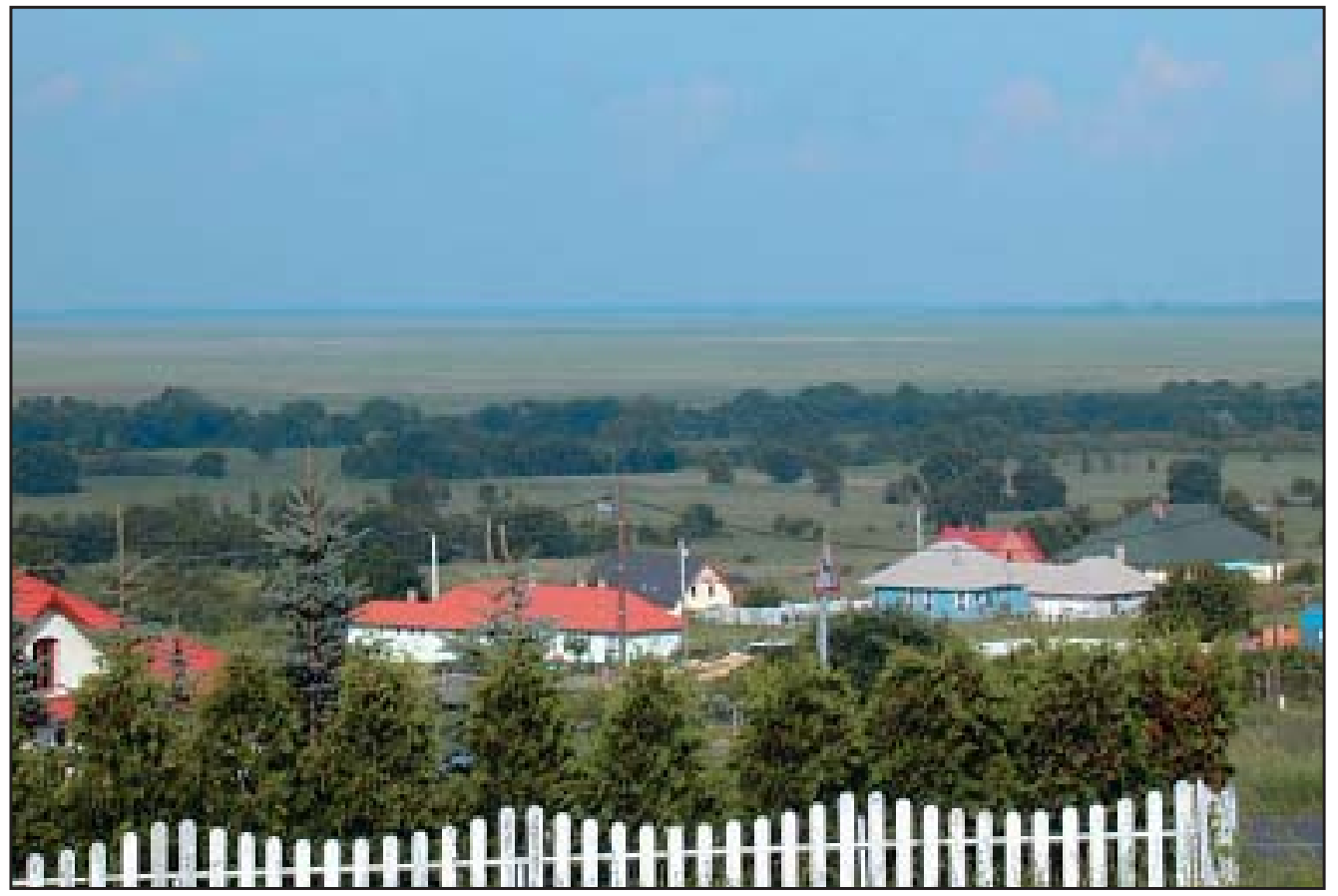

Figure 8: There is a great difference in character between the protected and non-protected areas around Lake Fertó (photography Éva Konkoly Gyuró). 


\subsubsection{Communist dictatorship}

After WW II farmers either voluntarily joined or were forced to join cooperative farms, or they fled to towns. The situation was even worse in border areas, especially close to the Austrian border. Villages of the western borderland lost a great part of their population because of different political and economic constraints. The cultivated areas decreased not only because of land abandonment in the Fertó-region, but also because of the spreading plantations in the Hanság. In the 1970's this region partly escaped the large-scale agricultural intensification and modernization which were characteristic all over Europe, but the communist regime had no respect for traditions and historic buildings. Within ten to twenty years, people's set of values changed completely. They no longer valued handicrafts and traditional forms of production and furthermore they did not feel any responsibility for the environment. No one considered the land of cooperative farms or public places as their own. Moral self-control of the community gradually weakened. The population was growing old, as the younger generation started migrating to towns. The alienation from landscape was typical in the lowlands where large-scale water reclamation and collective farming took place (Hanság).

A different tendency could be seen in the hilly areas near to Lake Fertó, where vegetable and wine growing had long been a tradition. Holiday homes and leisure gardens appeared as new landscape features, especially in the vineyard area near Lake Fertó, as well as on the outskirts of the town of Sopron and in the vicinity of bathing resorts. Today, the area of mixed utility/recreation gardens is sometimes larger than that of the settlements themselves.

\subsubsection{Towards Europe (from 1990)}

The differences between the Fertó and Hanság regions became even more significant. The Fertó region is flourishing mainly owing to the opening of the borders. The quality of its landscapes encourages tourism and thanks to the private sector many old buildings are being restored in an authentic manner. Outdoor activities, cultural pursuits, summer holiday-making, and ecotourism are on the rise. At the same time, there are more and more conflicts with the interests of nature protection. The grasslands and wetlands, controlled by the National Park, are negatively affected by tourism. There is a great difference in character between the protected and non-protected areas. The Lake Fertó region was designated as a World Heritage cultural landscape. The greatest challenge of the future is to restore the harmony between natural and cultural heritage preservation and the development of the region.

The effects are taking longer to reach the Hanság, where the villages have not yet experienced significant dynamism. On the plains divided by forest belts the grasslands provided the main types of livelihood in the last two centuries. Gradually, the quantity of livestock decreased while arable land and forests increased. The inhabitants of today's villages are not really interested in the traditions of the landscape they live in. Nevertheless, in the vicinity of the border, »Austrian-like « building and planting styles are spreading. It is only to be hoped that in the near future some protective measures will be implemented, because soon there will be nothing akin to the historic landscape, except perhaps a few patches which the National Park looks after.

\subsection{The Roztocze case (Poland)}

Roztocze covers areas in Poland and the Ukraine on the Vistula and the Bug interfluve. It is mainly composed of calciferous plateaux and hummocks elevated up to $400 \mathrm{~m}$ above sea level. Its western part is called the Goraj and Szczebrzeszyn Roztocze, in the central part lies the Tomaszow Roztocze and the southern part is occupied by Rawa Roztocze (Buraczynski 1997).

The region used to have a variegated ethnical structure as numerous privileges aimed at enhancing trade attracted Jews and Armenians as early as the $16^{\text {th }}$ century. During the period of loss of independence (1772-1918), Roztocze was distinguished by the low level of economic growth and by large population 


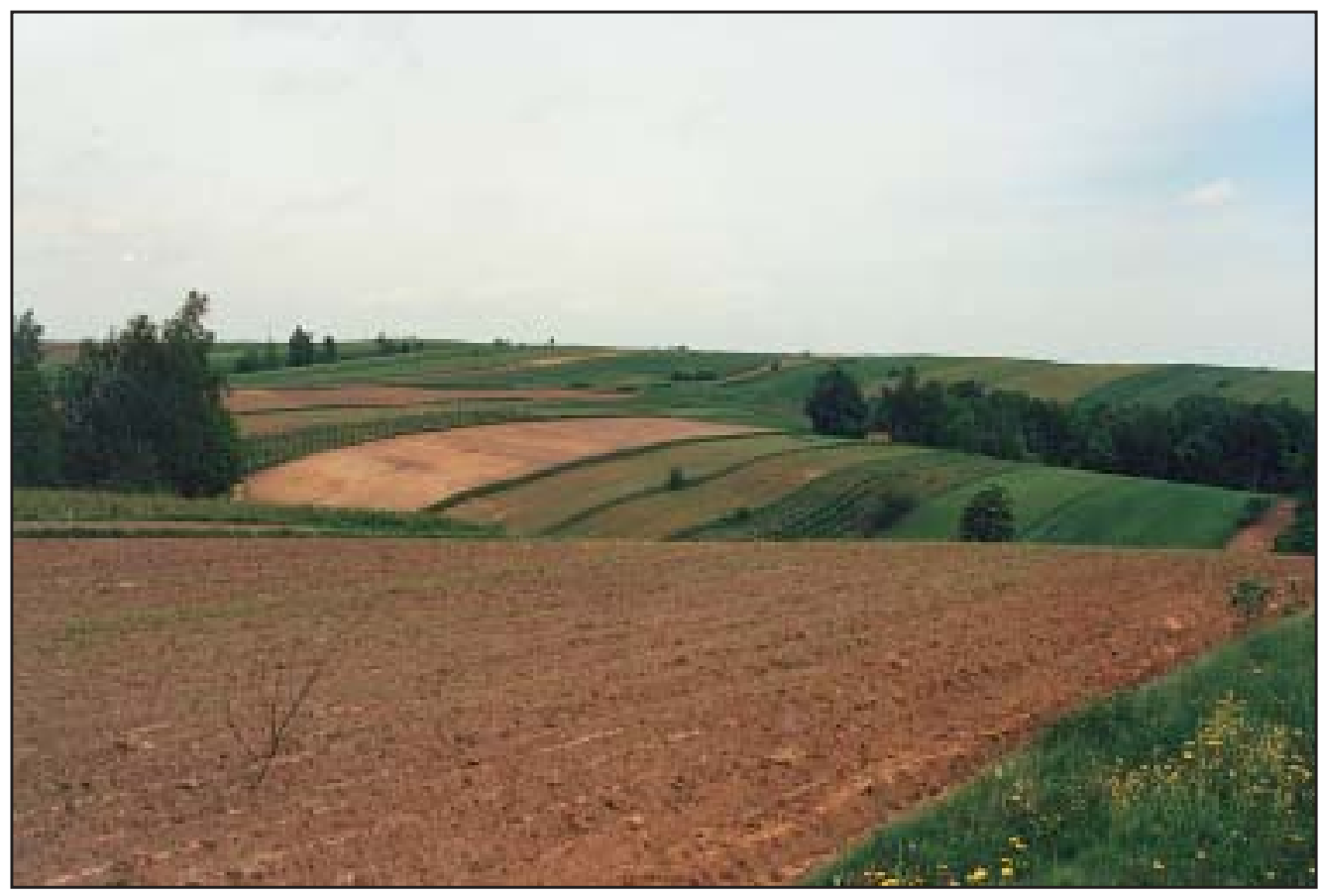

Figure 9: Sochy - a traditional agricultural landscape of the Central Roztocze (photography Ewa Skowronek).

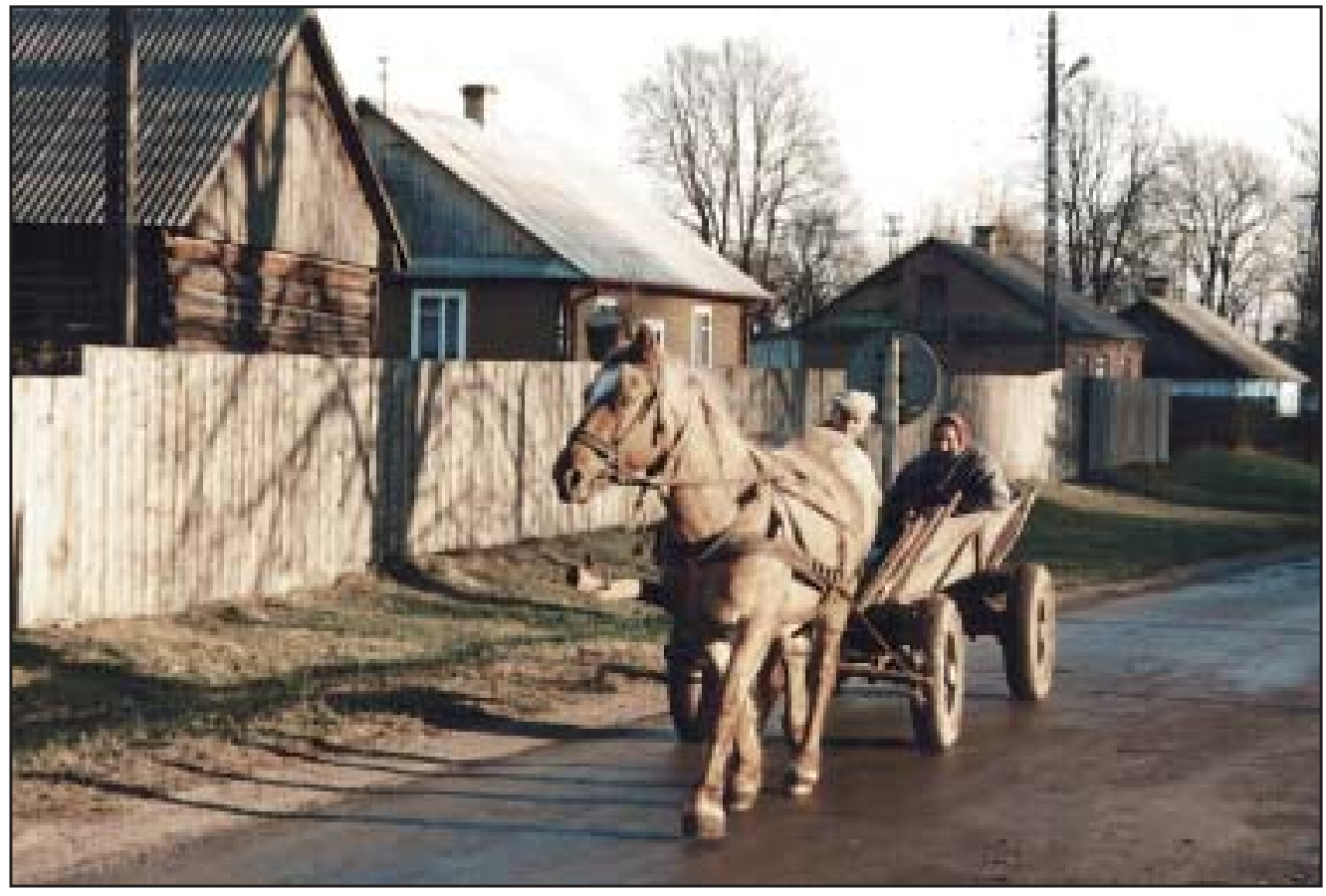

Figure 10: Guciow - a typical village in the Central Roztocze region (photography Waldemar Kociuba). 


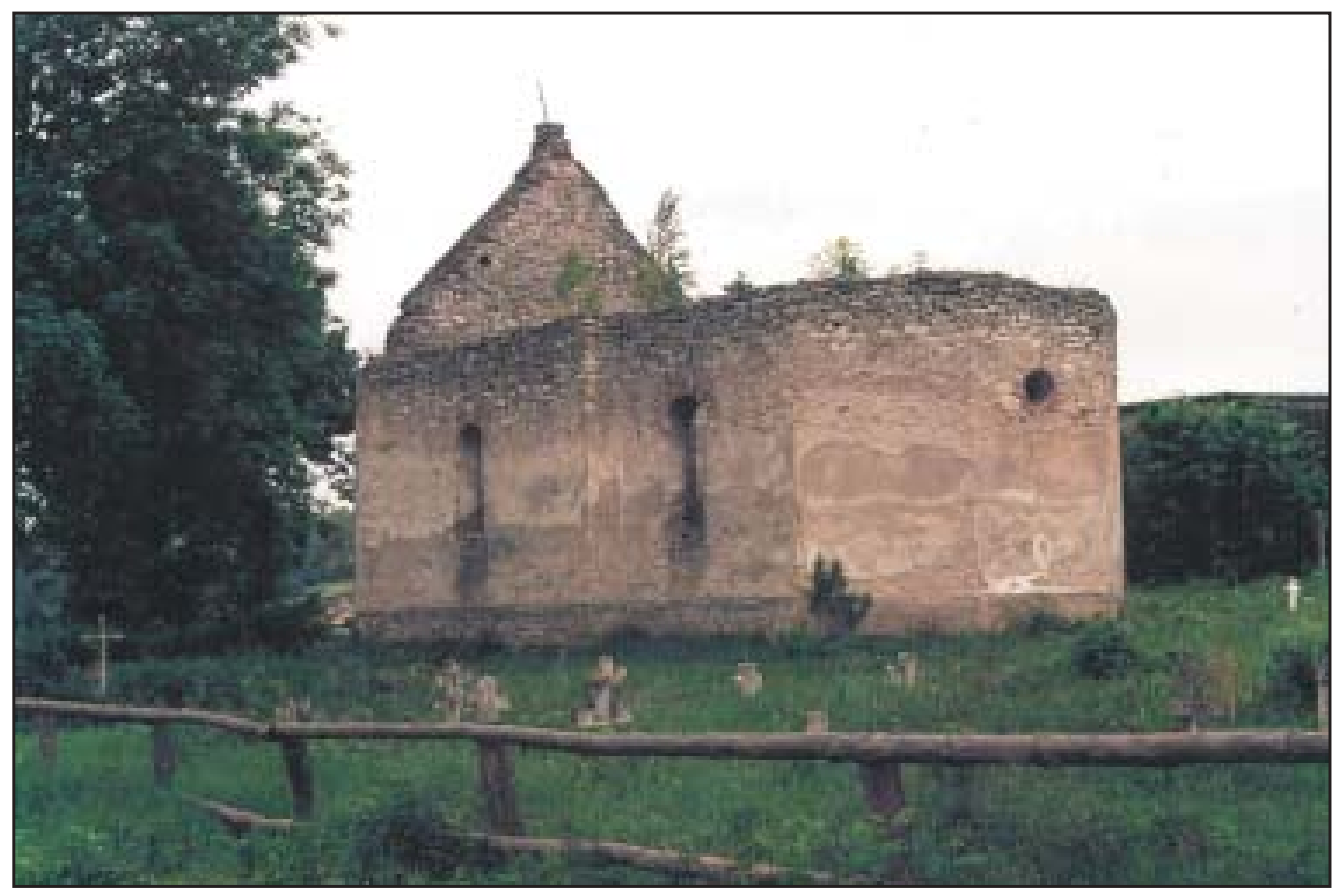

Figure 11: The former Orthodox Church and the cemetery in Huta Rozaniecka - Central Roztocze (photography Teresa Brzezińska-Wójcik).

density (Skowronek 1999). Agriculture was the basic source of income of the inhabitants of both small towns and villages. Villages were overpopulated, farms were small and arable land partitioned which generally was caused by the emancipation of the serfs in 1863 .

\subsubsection{Period from 1918 to 1945}

After Poland regained independence in 1918, no significant changes in the ethnical structure and landscape of the Roztocze took place. The religious structure reflected the ethnical one: the majority was Catholic and the minority was Orthodox and Jewish. A considerably different ethnical picture formed in the eastern part where $60 \%$ of the population consisted of Ukrainians, mostly adherents of the Greek-Catholic Church (Town ... vol. 4 and 13, 1924).

\subsubsection{Centrally planned economy (1945-1989)}

The structure of the population changed dramatically after WW II. Jewish settlements virtually ceased to exist (Chalupczak and Browarek 1998) and, due to border changes, the main centres of the Ukrainians were incorporated into the Ukrainian Socialist Soviet Republic. Those who stayed were resettled by the authorities to the western and northern part of Poland. Several dozen villages therefore became totally depopulated. The displacement of the Ukrainians entailed considerable material losses. Large villages were replaced by small settlements established in the vicinity of state farms. Large areas, previously densely populated, were re-afforested (Skowronek 1999). The changes did not affect the Goraj, the Szczebrzeszyn and the Tomaszow Roztocze - to such an extent. The settlement structure and the functions of the region were also preserved. Despite this, the size of the population shrunk. A quite different situation can be observed in Rawa Roztocze. Former landowners were forcibly displaced and their lands were subsumed into large state-owned land holdings. 


\subsubsection{Period after 1989}

Roztocze has unique natural and cultural values which have been created over centuries. These values relate to extraordinary environmental features, historical conditions and development of traditional agriculture. The region is poorly industrialised with an irregular settlement network and a low urbanisation rate (Skowronek, Krukowska, Swieca 2003). Individual farms operating at near-subsistence level predominate and land is highly fragmented as average farm size is less then 5 ha. The role and significance of cultural artefacts have been perceived as very important to local society. Moreover regional authorities would like to improve the present unfavourable economic situation through the development of tourism based on natural and cultural heritage.

From the environmental perspective it is noteworthy that the majority of agricultural land is located in the areas of key national and international importance. There are four landscape parks and one national park. It is feared that the modernization of agricultural production and possible farm amalgamation may result in the deterioration of the environment and the loss of value of agricultural landscapes and the cultural heritage. However, on the other hand national and international landscape protection requirements can provide a good basis for the preservation of environmental and cultural features and for the maintenance of a harmonious relationship between man and nature in the region.

\subsection{The Kras Case (Slovenia)}

Kras is a large limestone plateau approximately 500 square kilometres in size along The Trieste gulf. In spite of its less favourable natural conditions, it has always been inviting for settlement due to its proximity to the sea. In the past Kras was (and still is) a border region with important traffic routes which is one reason why the study of karst forms and phenomena began here and the region's name "Kras, « in slightly modified forms, became a terminus technicus.

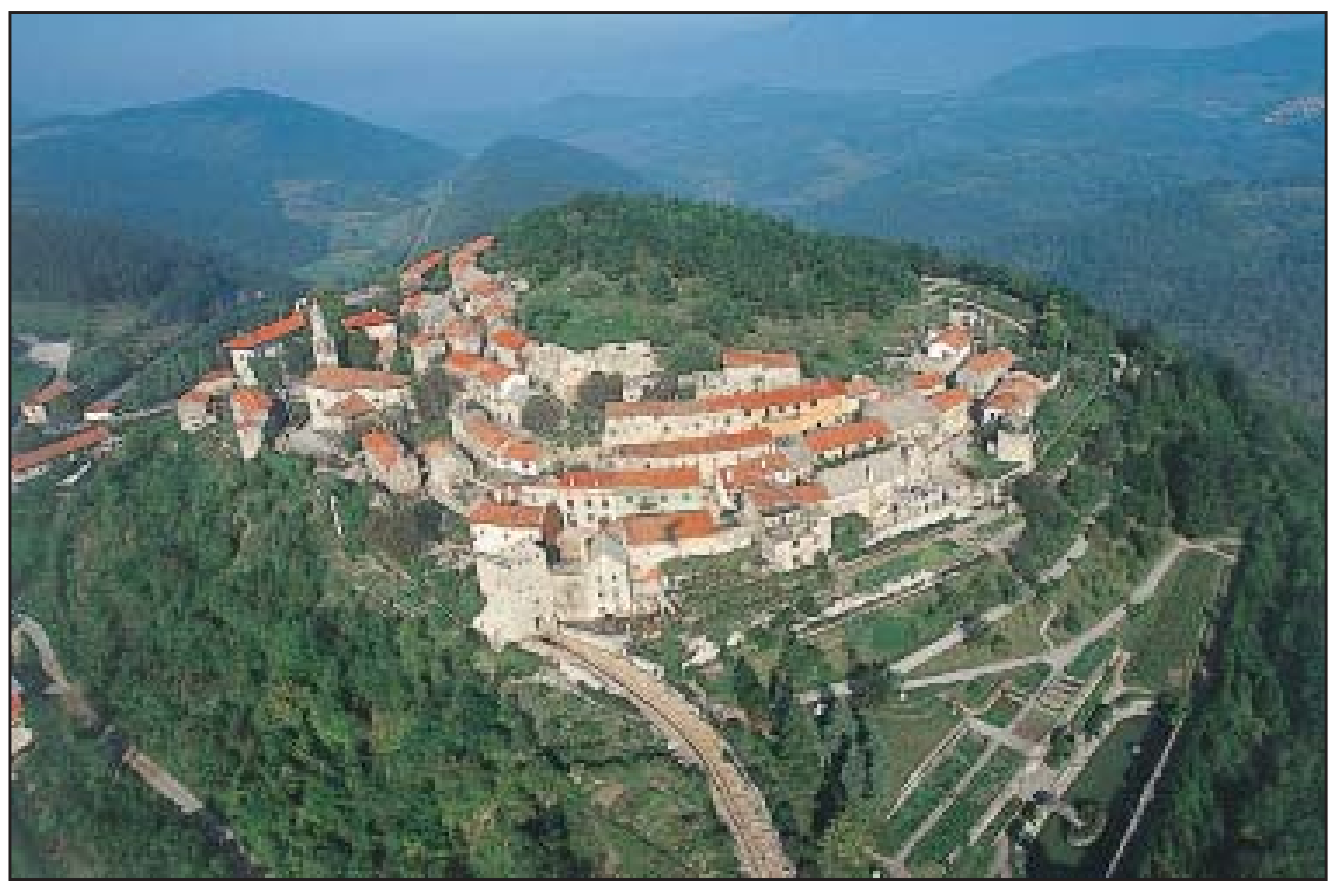

Figure 12: The sheltered south is characterised by settlements that give the impression of defensive strongholds, whereas the north is clearly seen as a densely forested, uninhabited landscape (photography Jože Hanc). 


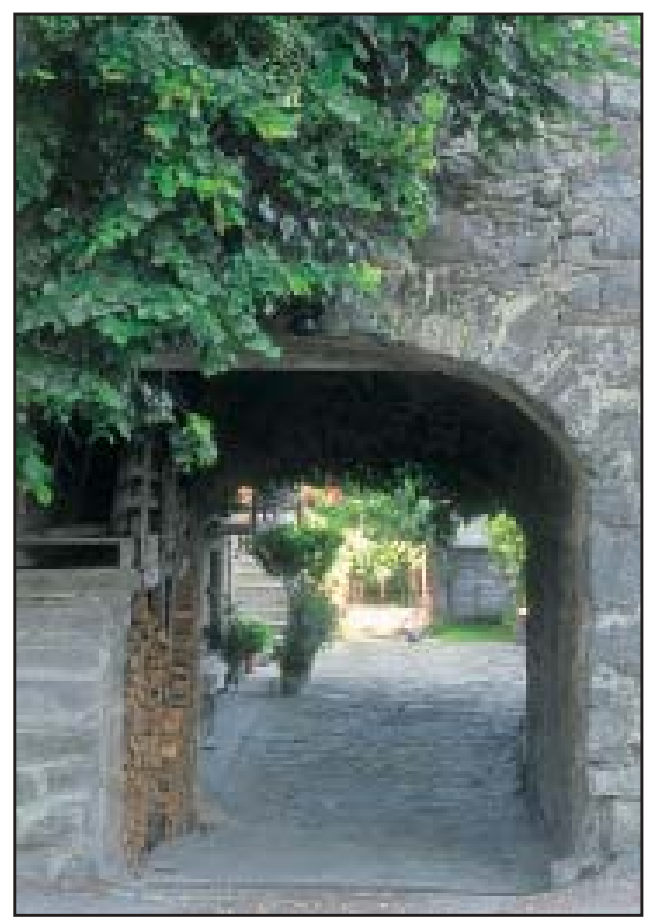

Figure 13: Porton 'courtyard entrance' reflects natural factors that placed their stamp on the landscape and the people: strong winds, the limestone bedrock, and the Mediterranean climate (photography Mimi Urbanc).

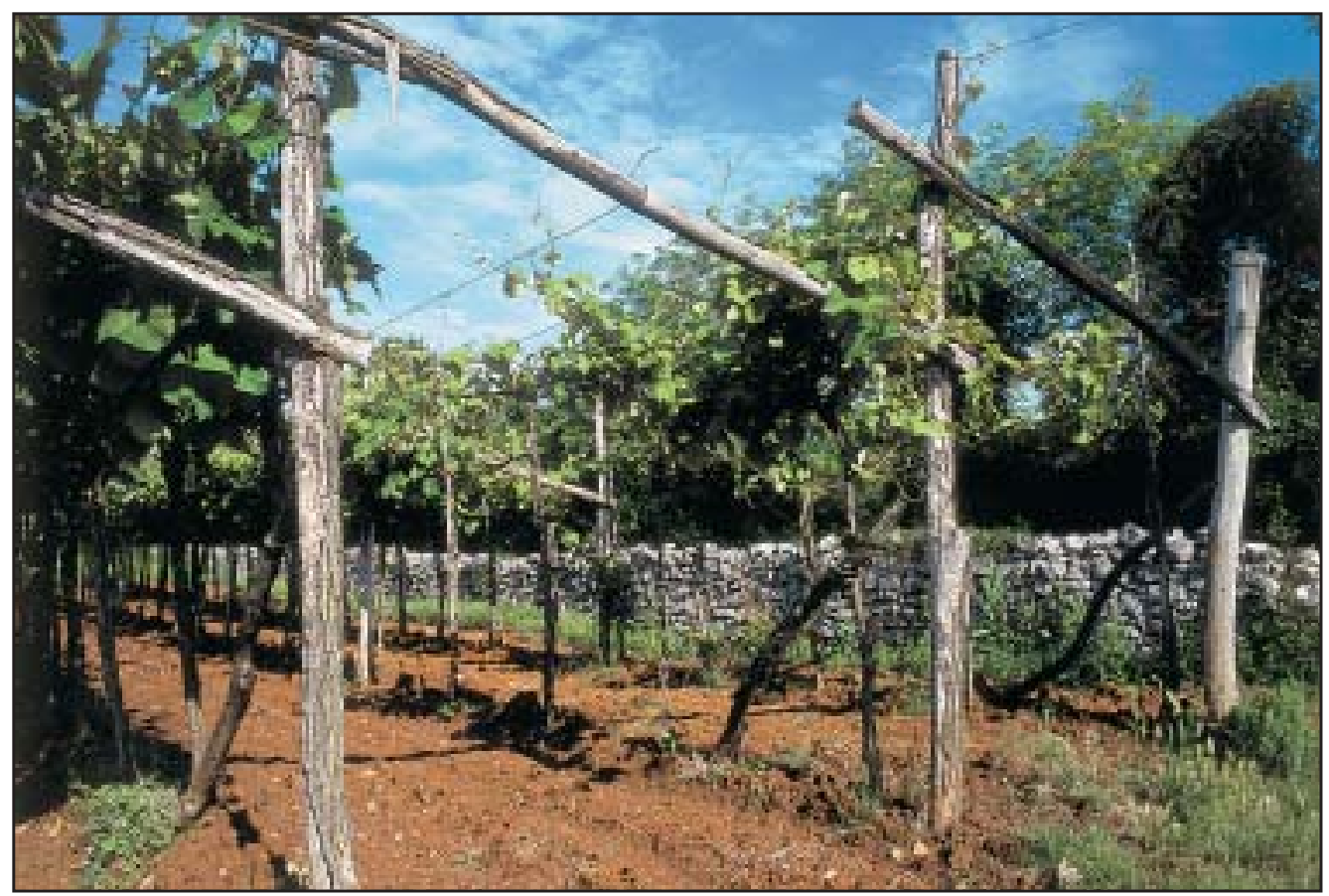

Figure 14: The most distinctive features of Kras are the Teran wine and the patches of characteristic terra rossa encircled by dry walls on which the vines are grown (photography Mimi Urbanc). 
The influences of various ethnic, economic, and social spaces met and intertwined here. Among the natural factors that placed their stamp on the landscape and the people are the bora, the limestone bedrock, and the Mediterranean climate. The Lipizzaner horse, Teran wine, and pršut (prosciutto) - the region's trademarks - reflect the characteristics of the landscape (Kladnik and Rejec Brancelj 1997).

\subsubsection{Italy (1918-1945)}

The initial post-war restoration of cultural, economic, and political life was followed after 1922 by ethnic, economic, ideological, and linguistic pressures that resulted in economic stagnation, the collapse of farms, and emigration. Fascist violence gave birth to resistance that drew from the ideas of Communism, and still today the people of Kras adhere to liberal political ideas. Agriculture was oriented toward supplying Trieste, which also offered jobs outside agriculture. The issues of agricultural decline were therefore not so pressing. The already small and fragmented farm properties diminished further owing to the Italian model of inheritance. A class of semi-farmers began to appear that produced wine and vegetables for Trieste and simultaneously sought part-time seasonal work there.

\subsubsection{Yugoslavia (1945-1991)}

The previously single territory was divided between Yugoslavia and Italy and Trieste, the region's centre, fell on the Italian side of the closed border. The period of economic and population decline ended after the border was opened in 1960, when the so-called "green border " reconnected Slovenia with Western Europe. People began to return because of the development of industry in the cities on the edge of Kras and the development of service activities related to transportation and the border. Due to the fragmentation of land ownership, the proportion of farmers continued to drop and the proportion of semi-farmers, who were still strongly attached to land and therefore clung to traditional farming, increased. Commerce with Trieste was revived, and simultaneously this relationship acquired a new dimension as the people of Trieste began to visit Kras and thus gave tourism a strong boost. Many villages lost their rural function and became residential settlements for the non-farming population (Perko 1998). Kras did not experience radical changes in property ownership because there were no large estates to be nationalized. Therefore, along with the lack of natural assets, a lack of central political interest in the area, somewhat ironically, contributed to the preservation of the landscape. The population increased slightly, largely due to larger centralized settlements and, at the same time, more remote settlements grew smaller. The settlement system remained basically unchanged, as did the outward appearance of settlements and houses. To a great extent, new buildings preserved regional characteristics in the choice of sites as well as in construction material and shapes. The bora wind, which allows no major departures from traditional patterns, probably contributed to this as well.

\subsubsection{Independent Slovenia (after 1991)}

Introduction of the free market brought changes. Stock farming collapsed to a great extent with resultant forest overgrowth (Gabrovec and Kladnik 1997). Features that reflect the effort and ingenuity of past generations (the cultivated sinkholes and rock walls) are disappearing. Winegrowing survives because it has different dynamics of work and is linked to the local identity. Two further factors are significant for the landscape's development: its geopolitical location and lifestyle trends. Trieste is an important employment centre, particularly for people seeking tax-free wages. Italian pensions are an additional bonus: they enable people to renovate their vineyards and houses or to start their own small business (Urbanc 2002).

Contemporary fashion includes the food and wine culture. Mediterranean and thus Kras food is considered healthy and above all delicious, and Kras has therefore long been a popular destination for day-tripping or for weekend tourists from Italy and from the rest of Slovenia. Kras is an area with a strong regional identity based on stone, wind, and terra rossa and the architectural heritage linked to these factors, the Lipizzaner, Teran wine and prosciutto. May 1, 2004, represents a new turning point, a new stage in the development because the region, divided for decades, was reunited. Given a well thought out approach to economic and social development this is likely to be a precious bonus. 


\section{Discussion: how to overcome people's alienation from landscapes?}

In summary, the case studies point to the following issues. First, all the cases show how different formations have had different influences on the people and landscape patterns in different countries, despite the fact that the succession of formations has been basically the same. Second, how socio-economic (and political) formations really do matter in daily life: how ideology as an underlying factor determines unfavourable natural conditions as suitable for settling, economic and other activities; how changes in geopolitics draw political borders, causing migration and a loss of identity; how trans-boundary landscapes evolve differently. Third, the remains of former formations are not wiped away consciously; rather, they vanish gradually, though some of the physical artefacts regain some value after some time has passed but this (regaining of some value) forms a basis for incomprehension of immediate surroundings In contrast to the third statement, the frequent changes of formations have led people to become more suspicious of change and have physical consequences: abandonment, illegal dumping (fly-tipping), ill-fitting infrastructures and inappropriate housing developments etc... Can we cope with estrangement? People are nowadays less connected to their land than they used to be. In the past land was the main or only source of income for a majority of people, so they were strongly associated with their property. Nowadays migration is a normal process in order to find employment, education and, generally speaking, better living conditions. Agriculture no longer constitutes the main (profitable) business for Europeans. Ties between people and landscape are not now formed by where they work, but by where they live and by their leisure pursuits.

On the other hand - the estrangement could be weaker than in Western Europe as we retain a more rural population and natural areas, with the result that this part of Europe could serve as an example of the lost harmony for urbanized Western Europe. In figure 15 it is referred to as traditional landscape with global characteristics. This is perhaps the best way for future developments of landscapes: local inhabitants as well as outsiders need the landscape. We cannot stop technological innovations (even in isolation), such as plastic haysacks, for example, but on the other hand they are still more desirable than abandoned overgrown fields (Palang, Alumäe, Mander 2000).

Antrop (1998) maintains that landscapes are dynamic phenomena and change constantly. Globalisation as an all-embracing and multi layered force acts as a motive power (Ogrin 1999). Antrop's list of forces

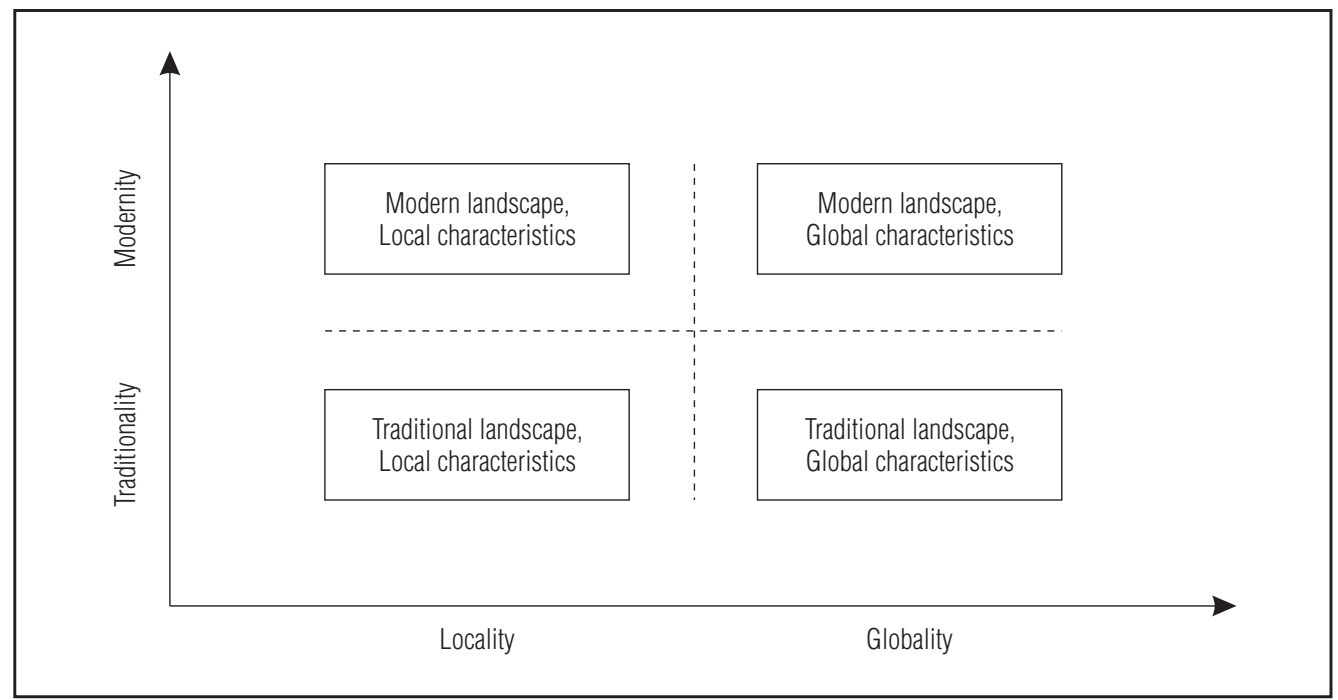

Figure 15: Future possibilities of landscapes (Palang, Printsmann, Alumäe, Kaur, Oja, Prede, Pungas, Reimann, Sooväli 2003). 


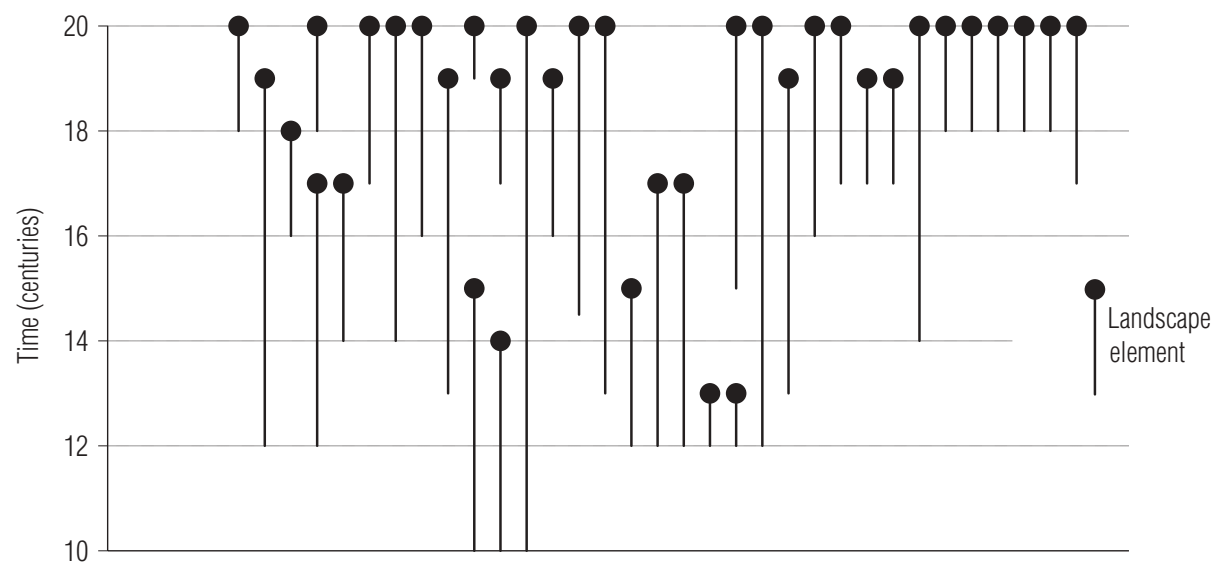

Landscape

Figure 16: Cultural landscape as a palimpsest (Vervloet 1986). Some landscape elements have remained the same through all the changing socio-economic formations. Some others have been forgotten or destroyed by the emerging formations. Some have been replaced by other objects. Yet others have retained their physical structure but the meanings have changed. Landscape is thus the collection of inscriptions by all formations, where one can still recognize the signs of different time periods.

that control landscape change includes also accessibility, urbanization, and calamities Antrop (2002). The threats to Eastern and Central European landscapes are under- and overexploitation, in globalizing terms: marginalization and intensification - both are diminishing the layered legacy of landscapes. The former closed areas are now open to everybody. Urban lifestyles are replacing the former rural ones. Globalization unifies the appearance and the functions of the landscape. We may try to induce landscape changes, but at the same time keeping local characteristics of the landscape (Figure 15). Or, we may try to introduce some global characteristics, but still try to maintain the traditional appearance. The worst future scenario would be modern landscape with global characteristics (e.g. golf courses) (see Palang, Printsmann, Alumäe, Kaur, Oja, Prede, Pungas, Reimann, Sooväli 2003 for more). Hence the turn to leisure and recreation studies and conflicts in planning between stakeholders and laypersons over what layers to preserve.

One of the possible solutions to the problem of estrangement is offered by landscape itself - it is a palimpsest (Figure 16). What is valuable will be retained, what is not valuable will disappear. But value systems keep changing, too. Some elements were considered valuable during the national states period then ignored during the Soviet era and became valuable again after independence (Alumäe, Printsmann, Palang 2003; Stenseke 1999). Up to the $20^{\text {th }}$ century a natural way of objects disappearing/remaining existed, since when we have started to conserve and preserve (see Gustavsson and Peterson 2003 for more) elements and landscapes per se. Remaining visible landscape elements can find new meanings in future formations and generations. In this sense landscape is patrimony also in Central and Eastern Europe: it is a container of material artefacts, thus tangible, and it is the most fixed phenomenon in our environment. We value the input of our predecessors and ancestors into the landscape that creates our sense of identity. For comprehension of landscapes we need to acknowledge their historical layers and multitude of meanings that any landscape element as well as processes may have. This recognition has not yet impacted on the common consciousness as the term landscape lacks the dimension of time in everyday language. Change and coping with change needs time to take place in landscape as well as in language. 
Most importantly, awareness of the importance of landscape is increasing, especially in considerations of it as one important factor in the quality of one's personal life and consequently in the quality of life of the whole community. Landscape has an important influence in shaping people's minds, ideas, emotions, identities, etc. (Moore 1999). Even today people have an emotional need to belong to and have a place in the landscape. People consider landscape as a source of life and as a result of their own work. People expect landscape to be part of their life and see themselves as part of the landscape.

\section{Conclusion}

The paper shows how socio-economic changes in the $20^{\text {th }}$ century in Central and Eastern Europe have boosted the alienation of people from landscapes as changes were so rapid that people were not able to comprehend transformations let alone to adapt to them. The shift has been so profound that people in most cases do not understand the context of the former formations; at the same time these new layers are so attenuated that new-sprung landscapes have had no time to become part of most people's lives. That is true especially for the psychological dimension of landscapes which normally takes longer to become part of the tradition, but once it is ingrained it can be removed only by a revolutionary change or by a very slow process. The whole $20^{\text {th }}$ century was a vibrant period, the second half in particular. Politically induced social and economic changes were accompanied by natural development caused by urbanization, globalization and other societal processes. Forms, functions and meaning of landscapes are prone to change in time and therefore difficult to comprehend.

The most important thing is to enable people to identify with new meanings of their landscape and thus to set up a responsible relationship with it. Having a sense of belonging to the landscape as the place of one's family, community and heritage means that care for the self is closely linked with the care for the landscape. In order to attach people to their landscapes prudent and long-term measures are needed at local, national and European levels including appropriate assessment of natural and cultural values and their incorporation into feasible land management plans. Only far-sighted measures taking account of the particular social and economic conditions of local populations will enable landscapes to develop in a sustainable direction to become stabilized.

\section{Acknowledgement}

Estonian part of the project was supported by the Estonian Science Foundation, grant no. 5858 and Academy of Finland Research Programme no. 105304 Transboundary landscapes.

\section{References}

Alumäe, H., Printsmann, A., Palang, H. 2003: Cultural and historical values in landscape planning: locals' perception. Landscape interfaces. Cultural heritage in changing landscapes. Dordrecht.

Antrop, M. 1998: Landscape change: plan or chaos? Landscape and Urban Planning 41, 3-4. Amsterdam, Oxford, New York, Tokyo.

Antrop, M. 2000: Background concepts for integrated landscape analysis. Agriculture, Ecosystems and Environment 77. Amsterdam.

Antrop, M. 2002: Why landscapes of the past are important for the future. Landscape and Urban Planning 70, 1-2. Amsterdam, Oxford, New York, Tokyo.

Appleton, J. 1996: The experience of landscape. Chichester.

Bourassa, S. C. 1991: The aesthetics of landscape. London.

Buraczynski, J. 1997: Roztocze: structure-relief-landscape. Lublin.

Chalupczak, H., Browarek, T. 1998: National minorities in Poland 1918-1995. Lublin.

Claval, P. 2004: The languages of rural landscapes. European rural landscapes: persistence and change in a globalising environment. Dordrecht.

Cosgrove, D. E. 1984: Social formation and symbolic landscape. Madison. 
Harteisen, U. 2000: Die Senne. Eine historisch-ökologische Landschaftsanalyse als Plannungsinstrument im Naturschutz. Münster.

Gabrovec, M., Kladnik, D. 1997: Some new aspects of land use in Slovenia. Geografski zbornik 37. Ljubljana.

Gustavsson, R., Peterson, A. 2003: Authenticity in landscape conservation and management: the importance of the local context. Landscape interfaces. Cultural heritage in changing landscapes. Dordrecht.

Jääts, I. 1998: Setude etniline identiteet. Studia Ethnologica Tartuensia I. Tartu.

Jones, M. 2003: The concept of cultural landscape: discourse and narratives. Landscape interfaces. Cultural heritage in changing landscapes. Dordrecht.

Internet: http://www.coe.int/t/e/Cultural_Co-operation/Environment/Landscape/. (20. 12.2004).

Keisteri, T. 1990: The study of changes in cultural landscapes. Fennia 168, 1. Helsinki.

Kladnik, D., Rejec Brancelj, I. 1997: The human geography of Kras. Kras. Ljubljana.

Kohli, M. 1996: The problems of generation: family, economy, politics. Public lectures. http://www.colbud.hu/main/PubArchive/PL/PL14-Kohli.pdf (20.12.2004).

Konkolyné Gyuró, É. 2000: Tájszerkezet vizsgálat [Landscape structure analysis]. A FHNPark földrajzi információs rendszerének kifejlesztése [GIS system of the Fertö-Hanság National Park University of Western Hungary]. Sopron.

Konkolyné Gyuró, É. 2002: Tájkaraktert formáló történelem [Landscape character formed by history]. Paper presented on the conference: „Geographical History of Transdanubien«, in Press.

Lefebvre, H. 1991: Production of space. Oxford.

Lowenthal, D. 1997: European landscape transformations: the rural residue. Understanding Ordinary Landscapes. New Haven.

Mikesell, M. 2000: Culture. The dictionary of Human geography. Oxford.

Moore, D. K. 1999: Holdfast: At home in the natural world. New York.

Ogrin, D. 1999: Kulturna krajina: pojmi - problemi - vizija (Cultural landscape: ideas - problems - vision). Kulturna krajina v dinamiki varstva in razvoja. Ljubljana.

Olwig, K. R. 2002: Landscape, nature and the body politic: from Britain's renaissance to America's New world. Madison.

Palang, H., Alumäe, H., Mander, Ü. 2000: Holistic aspects in landscape development: a scenario approach. Landscape and Urban Planning 50. Amsterdam, Oxford, New York, Tokyo.

Palang, H., Fry, G. 2003: Landscape interfaces. Landscape interfaces. Cultural heritage in changing landscapes. Dordrecht.

Palang, H., Printsmann, A., Alumäe, H., Kaur, E., Oja, T., Prede, M., Pungas, P., Reimann, M., Sooväli, H. 2003: Local people as shapers of sustainability of rural landscapes. Ecosystems and sustainable development, vol. 2. Advances in Ecological Sciences 19. Southampton.

Põldmäe, R. 1938: Rahvakultuurist, eriti rahva lõbutsemis vormidest Setumaal. Eesti Rahvaluule Arhiiv. Tallinn.

Perko, D. 1998: Prebivalstvo. Geografija Slovenije. Ljubljana.

Perko, D., Orožen Adamič, M. 1998: Slovenija - pokrajine in ljudje (Slovenia - landscape and people). Ljubljana.

Ränk, G. 1957: Eesti kultuuri piiripost kagus. Meie maa. Eesti sõnas ja pildis IV. Lõuna-Eesti.

Relph, E. 1986: Place and placelessness. London.

Robertson, I., Richards, P. 2003: Studying cultural landscapes. London.

Sauer, C. O. 1925: The morphology of landscape. Reprinted in Leighly, J. 1963: Land and life: selection from the writing of Carl Ortwin Sauer. Berkeley, Los Angeles.

Schama, S. 1995: Landscape and memory. New York.

Simonsen, K. 1996: What kind of space in what kind of social theory? Progress in Human Geography 20, 4. London.

Skowronek, E. 1999: Anthropogenic transformations of the Roztocze landscape as exemplified by the Biala Lada and upper Wieprz drainage basins. Doctoral dissertation, manuscript. Lublin.

Skowronek, E., Krukowska, R., Swieca, A. 2003: Transformations of cultural landscape: the case of the Polish-Ukrainian borderland. Landscape interfaces. Cultural heritage in changing landscapes. Dordrecht. 
Stenseke, M. 1999: Landscape perspectives on landscape values. Shaping the Land, vol. 3: The future of the past. Proceedings of the Permanent European Conference for the Study of the Rural Landscape. Trondheim.

Town Index for the Polish Republic, vol. 4, 1924. Warsaw.

Town index for the Polish Republic, vol. 13, 1924. Warsaw.

Tuan, Y. 2003: Space and place: the perspective of experience. Minneapolis, London.

Urbanc, M. 2002: Kulturne pokrajine v Sloveniji [Cultural landscapes in Slovenia]. Ljubljana.

Valk, H. 1996: Aegadest ja ajatunetusest Setomaal. Palve, vanapatt ja pihlakas. Setomaa. Vanavaravedaja 4. Setomaa 1994. Tartu.

Vervloet, A. 1986: Inleiding tot de historische geografie van de Nederlandse cultuurlandschappen. Wageningen.

Vos, V., Meekes, H. 1999: Trends in European cultural landscape development: perspectives for a sustainable future. Landscape and Urban Planning 46. Amsterdam, Oxford, New York, Tokyo. 


\section{Uvod}

V članku želimo prikazati, kako mehanizmi dojemanja pokrajine delujejo v Srednji in Vzhodni Evropi in kakšne posledice ima to za pokrajino. Razumevanje pokrajinskih prvin in procesov omogoča boljšo kakovost življenjskega okolja, kar je tudi cilj Evropske konvencije o krajini (medmrežje). Prepričani smo, da se srednje- in vzhodnoevropski pogled na pokrajino razlikuje od pogleda v preostali Evropi, ki jo je zaznamoval stabilnejši družbenopolitični razvoj. Hitro menjavanje družbenopolitičnih ureditev je ključnega pomena za (ne)razumevanje pokrajinskih sprememb v tem delu Evrope, vendar to (ne)razumevanje kljub sorodnemu toku dogodkov ni enotno. Različne zgodovinske in politične okoliščine so namreč $\mathrm{v}$ različnih državah povzročile različno dojemanje pokrajine in $\mathrm{v}$ nadaljevanju tudi neenotne strategije obvladovanja pokrajinskih sprememb, kar je vodilo v samosvoje smeri razvoja.

V znanstvenih krogih je znanih več razlag izraza pokrajina (glej Antrop 2000; Claval 2004; Jones 2003; Keisteri 1990; Olwig 2002; Palang in Fry 2003; Sauer 1925). Lowenthal (1997) navaja, opirajoč se na stabilnost zahodnega sveta, tri razloge, zaradi katerih naj bi pokrajino pojmovali kot dediščino. Prvič, pokrajine so materialne, saj jih dojemamo z vsemi čutili, zato so otipljive. Drugič, pokrajina nastopa v vlogi shrambe najrazličnejših artefaktov, daje jim širši kontekst in torej poudarja njihovo posamično vrednost. In končno, pokrajina je najbolj stalen, negiben pojav v našem okolju. Zaradi te lastnosti nam daje občutek varnosti in zanesljivosti. Za razliko od humanističnih pristopov (med drugimi Relph 1986; Robertson in Richards 2003; Tuan 2003), prevladujočih v anglo-ameriški kulturni geografiji v drugi polovici 20. stoletja, so se v Srednji in Vzhodni Evropi pod nemškim in ruskim vplivom osredotočili bolj na fizične pokrajine (Harteisen 2000; Perko in Orožen Adamič 1998) kot na pokrajine, kakor jih razumejo ljudje. To se je začelo spreminjati šele po zatonu komunizma, ko so lokalne skupnosti skupaj s svojimi običaji in tradicijami dobile večjo vlogo pri oblikovanju lastnega okolja tako na etični kot praktični ravni (Mikesell 2000).

Glede na povedano je pomembno poznati pomen izraza pokrajina v vsakodnevni rabi, ker je pokrajina medij, ki povezuje ljudi in naravo (preglednica 1).

Preglednica 1: Pomen izraza pokrajina v vsakodnevni rabi v nekaterih srednje- in vzhodnoevropskih jezikih.

\begin{tabular}{|c|c|}
\hline \multirow[t]{5}{*}{ estonsko maastik } & $\begin{array}{l}\text { maa pomeni 'zemlja', 'dežela' in 'teren', pripona - stik kaže, da gre za moderno besedo, ki izvira z začetka } \\
\text { 20. stoletja. Izraz se je uveljavil s književnostjo in slikarstvom. }\end{array}$ \\
\hline & $\begin{array}{l}\text { 1. Označuje neke vrste ozemlje tako abstraktne (hierarhične) kot tudi konkretne velikosti } \\
\text { (gričevnate južnoestonske } \sim \text { e). }\end{array}$ \\
\hline & 2. je lahko tipičen del ozemlja (obalne e). \\
\hline & 3. kot vizualni izraz in videz okolice (gozdnate $\sim$ ) \\
\hline & 4. Pozneje je prišlo do premika v pomenu in sedaj govorijo metaforično o političnih ah, glasbenih ah itd. \\
\hline \multirow[t]{2}{*}{ madžarsko tàj } & $\begin{array}{l}\text { 1. Ozemlje (ne prevelikega obsega) z enotnimi ali skladnimi geografskimi prvinami (donavska } \sim \text {, gričevnata } \sim \text { ); } \\
\text { vidna narava okrog nas (zimska } \sim \text { ) }\end{array}$ \\
\hline & 2. Okolica, podeželje (okolica določene hiše) \\
\hline Poljsko krajobraz & $\begin{array}{l}\text { Kraj pomeni 'dežela' in obraz pomeni 'slika', 'pogled', torej lahko krajobraz prevedemo kot 'slika, podoba dežele'. } \\
\text { Izraz pomeni: pogled, slika ali scena bližnjega okolja (soseščine), fiziognomijo zemeljskega površja. }\end{array}$ \\
\hline \multirow[t]{4}{*}{ slovensko pokrájina } & $\begin{array}{l}\text { 1. Manjše ali večje ozemlje glede na oblikovanost, obraslost, urejenost: gorata } \sim \text {, tropska } ; \text { d določeno manjše ali } \\
\text { večie ozemlie nasploh: meala leži nad } \sim 0 \text { : Doleniska. }\end{array}$ \\
\hline & Primorska in druge slovenske $\sim$ e. \\
\hline & kateri je upodobljena pokrajina. \\
\hline & $\begin{array}{l}\text { 3. Knjiž., s prilastkom področje, območje: to so zanimive miselne } \sim \text { e; jur. Socialistična avtonomna Kosovo; } \\
\text { rel. cerkvena ; urb. kulturna : kultivirana . }\end{array}$ \\
\hline
\end{tabular}

V vsakdanjem življenju pokrajino običajno razumemo kot sliko, podobo, sceno, videz ozemlja. Poudarek je očitno na naravi, kar pomeni, da jo običajno dojemamo kot naravni pojav. Tako vsaj so se v šolah učile generacije ljudi. Seveda se pri natančnem razmisleku kulturni vidiki pokažejo kot pomembni, kljub temu pa so pojmovani kot manj značilni, in to zaradi subjektivnega značaja teh stališč. V obdobju komunizma so bili tovrstni pogledi v veliki meri zanemarjeni. Poleg tega se zdi, da v vsakdanji rabi izraza pokrajina niso zaobjeti dojemanje časa in družbeni, ekonomski ter politični vidiki. Očitno hitre spremembe pokrajine še niso našle poti $\mathrm{v}$ vsakdanji jezik. Jezik in $\mathrm{z}$ naravo povezane besede se zdijo inercijski, enako 
kot tudi ljudje fizično okolje dojemamo kot nekaj stabilnega, čeprav ni. Naše dojemanje narave kot nekaj močnega, s čimer moramo sobivati v sožitju, ali kot nekaj, kar moramo osvojiti ali braniti, se spreminja obenem z družbeno-ekonomskimi spremembami.

\section{Pokrajinske spremembe: čas in odtujitev}

Cosgrove (1984) je opisal, kako si vsaka družbeno-ekonomska ureditev prizadeva ustvariti svoje lastne pokrajine, $\mathrm{s}$ tem da poskuša izbrisati pomene in simbolične vrednosti prejšnjih ureditev in jih zamenjati s svojimi oziroma novimi. Ureditev moramo torej razumeti kot vrsto političnih, gospodarskih, družbenih, kulturnih in tudi ekoloških pogojev, prevladujočih v družbi. V Zahodni Evropi so se ureditve menjavale postopno in prehodna obdobja so trajala desetletja, včasih celo stoletja. Tako je vsaka ureditev imela dovolj časa, da je razvila svoje lastne pokrajine. Skozi umetnost in stike se je izoblikoval pokrajinski ideal (predstava), ki so mu pozneje sledili pri načrtovanju razvoja (Vos in Meekes 1999). Ideal vsebuje spomine preteklosti, ki jih je tako prepričljivo opisal Schama (1995), in pogoje za prihodnost.

Srednje- in vzhodnoevropske dežele so v 20. stoletju preživele vrsto družbeno-ekonomskih ureditev, zaradi česar so bile izpostavljene globokim in obsežnim spremembam pokrajinskih oblik, pomenov in dojemanja posameznih prvin, kar je povzročilo slojevite pokrajine. Tako je cesarskim pokrajinam pred letom 1918 sledilo rojstvo narodnih držav, pojav nacionalnih čustev v Estoniji, na Poljskem ter v Sloveniji in razočaranje na Madžarskem zaradi izgubljenega ozemlja po prvi svetovni vojni. Obdobje po drugi svetovni vojni je prineslo na komunističnih in socialističnih idejah temelječe vrednote, pojave, prakse in predstave. Leto 1990 je ponovno prineslo obrat, tokrat v smeri »Zahoda«: hitro nazadovanje kmetijstva in na novo opredeljevanje pomena pokrajine. S tem člankom želimo dokazati, da je odtujitev od pokrajine v tem obdobju (20. st.) dosegla vrh in tako povzročila izgubo tradicionalne pokrajinske identitete ter posledično tudi okoljske probleme.

V postmodernem času so nekatere prvine preteklih ureditev izbrisane, nekateri materialni in duhovni ostanki pa so preživeli in tako pomagajo sestaviti mozaik celostne zgodovine, čeprav so se njihove funkcije in pomeni lahko spremenili. Za boljše razumevanje tega, kaj se v resnici spremeni, ko se spremeni pokrajina, moramo pojasniti prepletanje (Palang in Fray 2003) med duhovno in materialno sfero in vzročnimi dejavniki (slika 1) v pokrajini v časovni dimenziji. Appleton (1996) je pokazal, da na vedênje človeške družbe, ki povzroči spremembe v pokrajini, ne vpliva okolje neposredno, marveč človekov odnos do njega (okolja), ne tak, kot je, ampak tak, kot se mu zdi, da je. Drugače povedano, pomembna je podoba (predstava) okolja, in ta podoba je lahko popačena na različne načine.

Slika 1: Model pokrajine (Keisteri 1990)

Glej angleški del prispevka.

Glavni vzrok popačenja podobe okolja je ideologija trenutne družbeno-ekonomske ureditve. Lefebvrovo (Lefebvre 1991) stališče je, da prostorska praksa (Simonsen, 1996, jo imenuje družbena prostorskost), ki je dialektična interakcija med družbo in njenim življenjskim okoljem, v sebi združuje prostorske predstave in prostore predstav. Prostorske predstave so sestavljene iz ideologije; to je prostor kot predstava (tudi mišljeni pojmovani prostor), kjer so prizorišča za dejanja dana vnaprej in se razlikujejo od ureditve do ureditve. Prostor predstav je živi prostor (tudi doživeti prostor), kjer imajo stvari pomen. Prostorska predstava je kot shramba najrazličnejših uporabnih pomenov, ki jih določa ideologija, zato mnogim pokrajinskim prvinam, v kolikor ne izginejo, pripisujemo nove vrednosti. Odtujitev izvira iz neskladnosti med ohranjenimi prvinami, katerih pomen se je v času menjav družbenopolitičnih ureditev spreminjal, in med novimi prvinami, ki nosijo simbolni pomen aktualne ureditve.

Ideologija družbeno-gospodarske ureditve sama po sebi ne povzroči odtujitve, marveč je ta stranski učinek pogostih preobratov ureditev v Srednji in Vzhodni Evropi. Bourassa (1991) opisuje tri različne ravni pokrajinske izkušnje: biološki zakon, kulturna pravila in osebne strategije. Odtujitev je pogojena z družbenim razvojem - ne moremo pričakovati, da bodo naši otroci cenili enake stvari kot mi, saj je generacijski konflikt neizogiben (Kohli 1996). Drugo stopnjo odtujitve (kulturne) umetno povzročajo družbene pred- 
stave, pripisovanje novih pomenov starim prvinam in nasprotja med uradnimi ideologijami in tradicionalnim načinom življenja. Tretja raven odtujitve (individualne strategije) nastopi, kadar so ljudje zaradi ukrepov oblasti ločeni od pokrajine; lokalni prebivalci zapustijo oziroma so prisiljeni zapustiti dom, na izpraznjeno območje pa se naselijo novi ljudje.

Izbrana testna območja Estonije, Madžarske, Poljske in Slovenije (slika 2) kažejo spremembe v rabi tal, ekoloških razmerah, pomenu in simbolnih pokrajinskih vrednotah, ki izhajajo iz družbeno-gospodarskih preobratov. Nadalje so dokaz, da je pogosto prevrednotevanje pokrajin povzročilo odtujitev ljudi in pokrajine in s tem nepričakovane spremembe, na katere so dodatno pritiskali drugi družbeno-ekonomski procesi, kot sta urbanizacija in industrializacija.

Slika 2: Izbrana testna območja.

Glej angleški del prispevka.

\section{3 Štiri testna območja}

\subsection{Setu $^{2}$ (Estonija)}

Setu je območje, ki je bilo in je spet razdeljeno med Rusijo in Estonijo. Leži na stiku pravoslavne in katoliške cerkve in med slovanskimi in ugro-finskimi narodi. Obmejna lega pomeni prednost pri ohranjanju tradicionalnih kulturnih potez. V 19. stoletju so Setujci še poznali skupno lastništvo zemlje, kar je zaviralo lastno iniciativo in razvoj gospodarstva. Poleg tega se jih zaradi nepismenosti romantično gibanje in narodno prebujenje nista dotaknila. Po ponovni vključitvi v Estonijo (1920) se je setujska kultura vse bolj približevala estonski. Dolgotrajen ruski vpliv je opazen v kulturni podobi: ruski pravoslavni cerkvi, arhitekturi, narodnih nošah, ljudskih plesih, pripovedkah itd. Zaradi ločenosti od drugega dela dežele so nekatere južnoestonske prvine dobro ohranjene. Setujci niso Rusi, pač pa Estonci z zelo samosvojo kulturo.

\subsubsection{Republika Estonija (1918-1940)}

Družbeno in kulturno življenje se je začelo prilagajati organiziranosti matične dežele in v šole je bila kot učni jezik uvedena estonščina. Med kulturnimi značilnostmi je ruska pravoslavna veroizpoved odigrala najpomembnejšo vlogo pri oblikovanju samozavesti (Estonci so luterani), čeprav se je prepletala s starimi poganskimi verovanji. V vsaki dnevni sobi je bil še vedno »sveti« ali »božjii kót (Ränk 1957). Stari poganski običaji so bili na eni strani odsev nizke izobrazbene stopnje, na drugi pa samozavesti in odpora proti sprejemanju novosti, še zlasti, ker je bila njihova kultura zelo ranljiva. Problem alkohola je bil prisoten že takrat. Pretepi na vaških zabavah so bili večinoma povezani z njim, bili pa so tudi odsev razvojne stopnje naroda, ki je izgubljal svojo identiteto in kulturno enotnost (Ränk 1957). V obdobju estonske samostojnosti se je setujska kultura sicer razvijala, a se je vse bolj oddaljevala od ruske. Narodna noša se je ohranila, vendar se je njen pomen zmanjšal. Zemljiška reforma je prinesla večjo gospodarsko moč. Za Estonce so bili Setujci nižji sloj, čeprav so jih zlasti izobraženci šteli za pomembne, saj so pričali o ugro-finski preteklosti. Uradna politika si je prizadevala za njihovo ponovno vključitev v estonsko državo.

Slika 3: Značilen setujski kmečki dom s poslopji okoli pravokotnega dvorišča. Navzven stavbe večinoma propadajo, njihova notranjost pa Estonce še vedno spominja na zlato dobo zasebnega kmetijstva iz 30. let prejšnjega stoletja (fotografija Mimi Urbanc).

Glej angleški del prispevka.

Slika 4: Večglasno zborovsko petje in praznična narodna noša sta pomembni prvini setujske identitete (fotografija Mimi Urbanc). Glej angleški del prispevka.

Slika 5: Ponovno odkrivanje korenin. Pred kratkim izrezljana figura poganskega boga plodnosti zraven vhodnih vrat je obenem tudi turistična znamenitost (fotografija Mimi Urbanc).

Glej angleški del prispevka.

\footnotetext{
${ }^{2}$ Pri pisanju besedila o estonskem testnem območju je sodeloval Kadri Semm.
} 


\subsubsection{Sovjetsko obdobje (1945-1991)}

Leta 1945 je bil del območja Setu priključen Ruski sovjetski socialistični republiki (SSR), saj je bilo narodnostno mejo zaradi mešanja Estoncev in Setujcev težko potegniti. Meja je bila le administrativna, večina estonskega ozemlja je bila v Estonski SSR, in ni prekinila dotedanjega razvoja. Kljub temu so nekatera naselja na ruski strani začela nazadovati (Jääts 1998). Kolektivizacija in oblikovanje kolhozov in sovhozov sta bila izvedena v letih 1947-1951. V 80. letih je cvetela t. i. »senčna« ekonomija. Vsaka družina je obdelovala svojo njivo kumar ali čebule in pridelke so prodajali v Pskovu in Leningradu (sedaj St. Peterburgu) (Jääts 1998).

Šolski sistem je spodbujal rabo estonskega jezika in obenem obravnaval vero kot ostanek preteklosti. Kljub temu so v začetku 50. let zgradili cerkvi v Obinitsi in Meeksiju, deloma ponoči na skrivaj, obenem pa je mladina uničila nekaj kapel. Starejši ljudje so živeli skladno s tradicijo, mlajši pa so se odselili, saj niso hoteli biti staromodni. Prikrivali so svoj izvor, kajti biti Setu je zaradi verske in kulturne tradicije pomenilo biti drugačen, manjvreden (Valk 1996).

\subsubsection{Republika Estonija (po 1991)}

Območje Setu (del, ki je na estonski strani meje) je obrobna pokrajina, ki jo zaznamuje nazadovanje gospodarstva in prebivalstva (Jääts 1998). Vasi so glasniki ruske pravoslavne cerkve (Valk 1996). Starejše generacije še vedno spoštujejo tradicijo (nedelja je Gospodov dan, prinašanje hrane na pokopališče, post), za mlajše pa je to preživeto. Starih vrednot ne potrebujejo več, še vedno pa nekateri spoštujejo narodno nošo. Meja med Estonijo in Rusijo (med domačini imenovana tudi Setujski zid, po Berlinskem zidu) je fizična ovira, ki omejuje gibanje (grobovi so na drugi strani meje, na primer). Zanimivo in presenetljivo je, da je ta delitev po drugi strani simbol enotnosti za Setujce in jih združuje v interesno skupino, ki se zaveda sebe in je politično aktivna. Spontano se je izoblikovala ob narodnem gibanju konec 80 . let. Sovjetsko obdobje domačini dojemajo kot uničenje lastne identitete in posledično je vse, kar je bilo cenjeno $\mathrm{v}$ tistem obdobju (kolhozi, stanovanjski bloki), danes popolnoma odveč in prezrto. Vse več je literature, ki predstavlja narodne noše in idealizira uravnoteženost ter trajnost tradicije. Kar je bilo v preteklosti odsev revščine, je danes sredstvo za ohranjanje tradicije, ki privlači turiste in s tem ustvarja dohodek.

\subsection{Fertő-Hanság (Madžarska)}

Z griči obdano nižavje Fertó-Hanság, ki leži na SZ Madžarske, obsega več kot $60 \mathrm{~km}^{2}$. V preteklosti so to pokrajino sestavljala med seboj povezana jezera in močvirja, zato so se prebivalci naučili živeti in gospodariti z vodo. V 18. in 19. stoletju je bila Madžarska zaradi naravnih danosti žitnica Habsburške monarhije. V drugi polovici 19. stoletja so naraščanje prebivalstva, zemljiška odveza in razvoj trgovine znotraj monarhije spodbudili razvoj kmetijstva, obenem pa tudi obsežne regulacije rek in izsuševanje močvirij, s čimer so nastale nove obdelovalne površine. Žal so se hitro pokazale negativne posledice teh posegov: prsti so se preveč izsušile, zato so uredili namakalne sisteme, ki so skupaj z novozgrajenimi cestami povsem spremenili pokrajino. V obmejnem gričevju ob jezeru Fertó pa so se ohranili tradicionalni načini rabe tal.

Slika 6: Moderna pokrajina v Hanságu, nastala po drugi svetovni vojni (fotografija Éva Konkoly Gyuró).

Glej angleški del prispevka.

Slika 7: Ohranjena kulturna dediščina v Hanságu (fotografija Éva Konkoly Gyuró).

Glej angleški del prispevka.

Slika 8: Zaščitena in nezaščitena območja ob jezeru Fertó se močno razlikujejo (fotografija Éva Konkoly Gyuró).

Glej angleški del prispevka.

\subsubsection{Obdobje med svetovnima vojnama}

Po koncu prve svetovne vojne sta bili dve tretjini nekdanjega ozemlja Madžarske priključeni sosednjim državam. Dežela je izgubila kar $87 \%$ nekdanjih gozdov in $85 \%$ travnikov, zato se je le s težavo soočala 
$s$ tako izgubo. Sistemi rabe tal in teritorialne delitve dela so propadli. Najbolj pomanjkljiva je bila oskrba $\mathrm{z}$ lesom. Velikopotezni nacionalni programi pogozdovanja so zaradi svetovne gospodarske krize in bližajoče se nove vojne ali v celoti propadli ali bili le delno izvedeni. Ti problemi so bili značilni tudi za preučevano območje in to kljub intenzivnemu pogozdovanju nekdanjih mokrotnih površin. Le manjši del območja je ostal nespremenjen (Konkolyné Gyuró 2000). Rast prebivalstva se je nadaljevala. V tem obdobju se je zaradi ugodnih naravnih danosti začel razvoj turizma ob jezeru Fertó. Plitva in prijetno topla voda je privlačila prebivalce Soprona in Dunaja in zrasla so prva počitniška središča. Poleg tega so na madžarski strani odkrili zdravilni žvepleni vrelec, ob katerem je nastalo veliko termalno kopališče.

\subsubsection{Komunistična diktatura}

Po drugi svetovni vojni so se kmetje prostovoljno ali pod pritiskom pridružili državnim posestvom ali pa so opustili obdelovanje zemlje in se preselili v mesta. Na območjih ob avstrijski meji je bil položaj še slabši. Število prebivalcev je zaradi različnih političnih ukrepov močno upadlo. Obdelovalne površine so se zmanjševale ne samo zaradi opuščanja kmetijstva v Fertu, marveč tudi zaradi topolovih nasadov v Hanságu. V 70. letih je to območje zaobšla velikopotezna intenzifikacija in specializacija kmetijstva. Komunistična oblast ni kazala nobenega spoštovanja do tradicije in stavbne dediščine, pa tudi vrednote ljudi so se popolnoma spremenile. Domača obrt ni bila več cenjena, enako tradicionalni načini obdelovanja, poleg tega niso več čutili spoštovanja do okolja. Nihče ni čutil pripadnosti do državnih posesti ali javnega prostora. Občutek moralne odgovornosti in samokontrole je v določeni meri še obstajal, vendar je počasi in vztrajno slabel. Prebivalstvo se je staralo, še posebej zaradi odseljevanja mladih v mesta. Odtujitev od pokrajine je bila še posebej očitna v nižavju, kjer so izvajali velikopotezne hidromelioracije in kolektivizacijo (Hanság). Precej drugačen razvoj je zaznati na gričevnatih območjih ob jezeru Fertő, primernih za vrtnarstvo in gojenje vinske trte. Okrasni vrtovi in počitniške hiše so se pojavili kot nova prvina v pokrajini, še posebej v okolici vinogradniških površin vzdolž jezera, pa tudi na obrobju Soprona in v bližini termalnih letovišč. Vikendska območja po velikosti danes presegajo tradicionalna vaška naselja.

\subsubsection{Smer: Evropa (po 1990)}

Razlike med območjema Fertő in Hanság postajajo vse očitnejše. Fertő je zlasti po odprtju meja doživel pravi razcvet. Turistična ponudba sloni na lepotah pokrajine in po zaslugi zasebnih pobud so številne stare stavbe obnovljene $\mathrm{v}$ avtentičnem slogu. Zdraviliški, kulturni, počitniški, kolesarski in ekoturizem so v vzponu. Obenem prihaja do vse pogostejših navzkrižij z naravovarstvenimi interesi. Travnate in močvirne površine, ki so pod nadzorom Narodnega parka, že čutijo negativne posledice turizma. Poleg tega se večajo razlike med zaščitenimi in nezaščitenimi območji. Jezero Fertó je bilo vpisano na seznam svetovne kulturne dediščine. Največji izziv za prihodnost je, kako vzpostaviti ravnovesje med ohranjanjem naravne ter kulturne dediščine in gospodarskim razvojem območja.

Območje Hansága zaostaja, saj naselja še ne beležijo večjega oziroma intenzivnejšega razvoja. Na ravninah, ločenih s pasovi gozda, so v zadnjih dveh stoletjih travnate površine omogočale osnovni vir preživetja. Postopoma pa se je število živine zmanjšalo, povečale pa so se orne in gozdne površine. Sočasno tudi travnate površine postajajo vse bolj cenjene. Za njihovo ohranitev se večinoma trudi le Narodni park. Za prebivalce vasi je tradicija pokrajine, v kateri živijo, že izgubila svojo privlačno moč, kar je še posebej očitno z oddaljevanjem od avstrijske meje. V bližini meje je močan avstrijski vpliv, ki se kaže v gradnji in pri oblikovanju vrtov. Samo upamo lahko, da bodo v bližnji prihodnosti vpeljali določene zaščitne ukrepe, drugače kmalu ne bo niti ostankov historične pokrajine več, razen morda posameznih zaplat, podobnih naravni pokrajini, ki so pod zaščito Narodnega parka.

\subsection{Roztocze (Poljska)}

Roztocze leži na poljsko-ukrajinski meji na sotočju rek Vistula in Bug. Večinoma ga pokrivajo apnenčaste planote in gričevja v višini do $400 \mathrm{~m}$ nad morjem. Zahodni del se imenuje Goraj in Szczebrzeszyn Roztocze, osrednji del Tomaszow Roztocze in južni del Rawa Roztocze (Buraczynski 1997). 
V preteklosti je območje imelo pestro narodnostno sestavo, saj so trgovski privilegiji že v 16. stoletju pritegnili številne Žide in Armence. V obdobju izgube neodvisnosti (1772-1918) Roztozce zaznamujeta počasna gospodarska rast in prenaseljenost (Skowronek 1999). Kmetijstvo je bilo osnovni vir preživetja tako podeželskega kot tudi mestnega prebivalstva. Podeželje sta zaznamovali agrarna prenaseljenost in razdrobljena posest; slednja je bila v veliki meri posledica zemljiške odveze.

Slika 9: Sochy - tradicionalna kmetijska pokrajina v osrednjem Roztoczu (fotografija Ewa Skowronek).

Glej angleški del prispevka.

Slika 10: Guciow - značilna vas v osredjem Roztoczu (fotografija Waldemar Kociuba).

Glej angleški del prispevka.

Slika 11: Nekdanja pravoslavna cerkev in pokopališče v Huti Rozaniecki v osrednjem Roztoczu (fotografija Teresa Brzezińska-Wójcik).

Glej angleški del prispevka.

\subsubsection{Obdobje med 1918 in 1945}

Po osamosvojitvi Poljske leta 1918 zahodni del preučevanega območja ni beležil večjih sprememb niti v nacionalni sestavi niti v podobi ter funkciji pokrajine. Verska struktura se je ujemala $z$ narodnostno: večina je bila katoliška, manjšina pravoslavna in judovska. Bistveno drugačna je bila podoba vzhodnega dela območja, kjer je bilo $60 \%$ prebivalcev Ukrajincev, v verski strukturi pa je močno prevladovala grška veroizpoved (Town Index, ... vol. 4 in 13, 1924).

\subsubsection{Centralistično plansko gospodarstvo (1945-1989)}

Struktura prebivalstva se je močno spremenila po drugi svetovni vojni. Židovska naselja so skoraj v celoti izginila (Chalupczak in Browarek 1998) in zaradi sprememb meje so bila osrednja naselja Ukrajincev priključena Ukrajinski SSR. Preostali Ukrajinci so bili z odlokom preseljeni v zahodni in severni del Poljske, tako da je nekaj deset vasi v Roztoczu skoraj popolnoma opustelo. Velika naselja so zamenjala majhna v bližini državnih posestev. Prej gosto poseljena območja je začel preraščati gozd (Skowronek 1999). Te spremembe Goraja, Szczebrzeszyna in Tomaszow Roztocza niso zajele v taki meri. Struktura naselij in tudi njihova funkcija sta precej ohranjeni. Kljub temu pa je število prebivalcev upadlo. Popolnoma drugačen je bil razvoju v Rawa Roztoczu, kjer so bili nekdanji lastniki na silo preseljeni, njihove kmetije pa so združili v velika državna posestva.

\subsubsection{Sodobna pokrajina (po 1990)}

Roztocze odlikujejo edinstvene naravne in kulturne prvine, ki so se oblikovale skozi stoletja in so povezane z zgodovinskim razvojem in tradicionalnim kmetijstvom. Območje zaznamujejo tudi propadla industrija, neustrezna naselbinska mreža in nizka stopnja urbanizacije (Skowronek, Krukowska, Swieca 2003). Zasebne kmetije imajo značaj samooskrbnih in so v povprečju manjše od 5 hektarov, saj je zemlja zelo razdrobljena. V zadnjih letih se odnos do kulturne dediščine spremenil: lokalna družba visoko ceni kulturne materialne ostanke. Poleg tega želijo regionalne oblasti izboljšati sedanji neugodni gospodarski položaj, in sicer z razvojem turizma, ki temelji na naravni in kulturni dediščini.

Z okoljskega vidika je pomembno, da je večina kmetijske zemlje na zaščitenih območjih, in sicer v okviru štirih krajinskih parkov in enega narodnega parka. Utemeljen je strah, da bi modernizacija kmetijske proizvodnje in pričakovane agromelioracije sprožile negativne okoljske procese in povzročile izgubo vredne kmetijske pokrajine in kulturne dediščine. Seveda pa so na drugi strani državni in mednarodni zaščitni ukrepi dobra osnova za ohranitev naravnih in kulturnih vrednot pokrajine in za vzdrževanje uravnoteženega odnosa med človekom in naravo.

\subsection{Kras (Slovenija)}

Matični Kras je obsežna apnenčasta planota v neposredni bližini Tržaškega zaliva. Kljub neugodnim naravnim razmeram je bil vedno privlačen za naselitev, zlasti zaradi bližine morja. Tako v preteklosti kot tudi 
danes je to obmejno območje s pomembnimi prometnimi potmi. To je bil tudi osnovni razlog, da se je preučevanje kraških pojavov začelo prav tu in da je ime pokrajine $\mathrm{v}$ rahlo spremenjeni obliki postalo terminus technicus. Pokrajina leži na stiku različnih etničnih, ekonomskih, družbenih in kulturnih vplivov. Med naravnimi prvinami, ki so odločilno vplivale na pokrajinski razvoj, je treba omeniti zlasti burjo, apnenčasto podlago in sredozemsko podnebje. Simboli lipicanec, teran in pršut odsevajo značilnosti pokrajine (Kladnik in Rejec Brancelj 1997).

Slika 12: Naselja, ki dajejo vtis trdnjave, so na zatišni južni strani, s severne strani pa Kras izgleda kot gozdnata in neposeljena pokrajina (fotografija Jože Hanc).

Glej angleški del prispevka.

Slika 13: Porton 'vhod' je odsev naravnih prvin, ki so oblikovale pokrajino in ljudi: močnega vetra, apnenčaste podlage in sredozemskega podnebja (fotografija Mimi Urbanc).

Glej angleški del prispevka.

Slika 14: Značilna rdeča prst in z njo povezano vino teran ter suhi zidovi so zaščitni znak Krasa (fotografija Mimi Urbanc).

Glej angleški del prispevka.

\subsubsection{Italija (1918-1945)}

Začetno povojno obnovo kulturnega, ekonomskega in političnega življenje je leta 1922 prekinil etnični, ideološki in jezikovni pritisk. Posledice so bile ekonomska stagnacija, nadaljnje propadanje kmetij in povečano izseljevanje. Fašistično nasilje je rodilo odpor, ki se je napajal z idejami komunizma, zato so Kraševci še dandanašnji zagovorniki liberalnih idej. Kmetijstvo je bilo usmerjeno v oskrbo Trsta, ki je ponujal delo tudi na drugih področjih. Zato agrarni problemi niso bili tako pereči. V tem času so se že tako majhne kmetije še zmanjšale tudi zaradi italijanskih dednih zakonov. Vse pogostejši polkmetje so pridelovali vino in zelenjavo za Trst in obenem tam iskali dodatno ali sezonsko zaposlitev.

\subsubsection{Jugoslavija (1945-1991)}

Prej enotno ozemlje je bilo razdeljeno med Jugoslavijo in Italijo in regionalno središče Trst je ostalo na drugi strani zaprte meje. Obdobje ekonomskega in gospodarskega nazadovanja se je končalo po letu 1960, ko je bila Slovenija s t. i. »zeleno mejo « ponovno povezana z Zahodno Evropo. Ljudje so se vračali, saj so se $\mathrm{v}$ mestih na robu začele razvijati industrija in storitvene dejavnosti, povezane s prometom in državno mejo. Zaradi majhnosti so kmetije še naprej propadale, manjšal se je delež kmetov in večal delež polkmetov, ki so bili še vedno močno navezani na zemljo. Oživela je trgovina s Trstom in sočasno so Tržačani začeli obiskovati Kras, kar je spodbudilo turizem. Naselja so postala domovanja nekmečkega prebivalstva (Perko 1998). Kras ni doživel pomembnejših sprememb lastništva, saj ni bilo večjih posestev, ki bi bila podržavljena. Tako so zanemarjanje s strani države in slabe naravne danosti pripomogli, da je pokrajina obdržala svojo tradicionalno podobo. Število prebivalcev je počasi naraščalo, zlasti na račun rasti osrednjih naselij, medtem ko so manjša in oddaljena naselja nazadovala. Naselbinski sistem je večinoma ostal nespremenjen, enako tudi zunanji videz naselij in hiš. Tudi nove stavbe so v veliki meri obdržale regionalni značaj, tako glede lokacij kot tudi materialov in oblik. K temu je pripomogla tudi burja, ki ni dovoljevala večjih odstopanj.

\subsubsection{Samostojna Slovenija (po 1991)}

Osamosvojitev je prinesla nazadovanje živinoreje in s tem zaraščanje nekdanjih obdelovalnih površin (Gabrovec in Kladnik 1997). Prvine, ki so odsevale trud in iznajdljivost preteklih generacij (delane vrtače, suhi zidovi), so začele propadati. Vinogradništvo se je obdržalo; tudi zaradi drugačne dinamike dela in navezanosti nanj. Za razvoj pokrajine sta pomembni dve dejstvi, in sicer geopolitični položaj in trendi v načinu življenja. Trst omogoča delovna mesta, zlasti za delo na črno, dodaten kapital pomenijo italijanske pokojnine, s pomočjo katerih obnavljajo vinograde, hiše ali ustanavljajo lastna podjetja (Urbanc 2002). Trendi vključujejo hrano in vino. Sredozemska in s tem kraška hrana velja za zdravo in predvsem za okusno, zato je Kras že nekaj časa zelo priljubljen cilj dnevnih in nekajdnevnih turistov iz Italije in notranjosti Slovenije. Kras je območje z močno uveljavljeno identiteto, ki temelji na kamenju, burji, rdeči prsti in arhi- 
tekturni dediščini in s tem povezanimi lipicanci, teranom in pršutom. 1. maj 2004 pomeni novo prelomnico v razvoju pokrajine, saj je desetletja ločeno območje postalo del skupne Evrope. Ob premišljenem gospodarskem in družbenem razvoju je to lahko velika spodbuda.

\section{Diskusija: kako preseči odtujitev ljudi od pokrajine?}

Na osnovi dognanj lahko ugotovimo naslednje. Prvič, vsa testna območja kažejo, kako so različne ureditve $\mathrm{v}$ posamičnih državah različno vplivale na ljudi in na pokrajinske vzorce, čeprav so si sledile v enakem zaporedju. Drugič, kako družbenoekonomske (in politične) ureditve v resnici vplivajo na vsakdanje življenje; kako ideologija kot vzročni dejavnik sprejme neugodne naravne razmere kot ustrezne za naselitev, gospodarsko rabo itd.; kako geopolitične spremembe rišejo politične meje in tako povzročajo migracije in izgubo identitete; kako se pokrajine na obeh straneh iste meje razvijajo različno. Tretjič, ostanki prejšnjih ureditev (običajno) niso odstranjeni zavestno, marveč izginejo postopoma, čeprav nekateri materialni ostanki po določenem času ponovno dobijo svoj pomen, kar pri ljudeh povzroči nerazumevanje neposredne okolice. Kot ugovor tretji trditvi moramo omeniti, da so zaradi pogostega spreminjanja družbeno-ekonomskih ureditev ljudje do sprememb vse bolj nezaupljivi, kar ima materialne posledice: depopulacijo, opuščanje gospodarske dejavnosti, divja odlagališča odpadkov, neustrezno infrastrukturo, arhitekturni razvoj, ki ne odseva duha regije itd. Ali se lahko spopademo z odtujitvijo? Vezi med pokrajino in ljudmi niso več tako močne, kot so bile. V preteklosti je bila zemlja osnovni, če ne edini vir preživetja, zato so bili ljudje nanjo močno navezani. Danes je preseljevanje običajen proces, in sicer zaradi iskanja službe, izobraževanja, na splošno zaradi boljšega življenja. Kmetijstvo Evropejcem ne pomeni več glavnega (dobičkonosnega) posla (okoli $5 \%$ ljudi se še ukvarja z njim). Vezi med ljudmi in pokrajino se nič več ne vzpostavljajo v delovnem okolju, marveč v okviru bivalnih in prostočasnih dejavnosti.

Na drugi strani pa je odtujitev lahko celo šibkejša kot v Zahodni Evropi, saj je na preučevanem območju več podeželskega prebivalstva in več ohranjenih naravnih območij, tako da bi ta del Evrope lahko služil kot vzor urbanizirani Zahodni Evropi in njeni izgubljeni harmoniji. Slika 15 prikazuje mogoče različice prihodnjih pokrajin, med drugim tudi tradicionalno pokrajino z globalnimi značilnostmi. To bi lahko bila najboljša pot prihodnjega razvoja pokrajin: tako lokalno kot tudi nelokalno prebivalstvo (outsiders) potrebujeta pokrajino. Tehnološkim inovacijam, okroglim plastičnim balam sena na primer, se ne da izogniti (niti v osami), na drugi strani pa so bolj sprejemljive kot opuščene površine (Palang, Alumäe, Mander 2000).

Slika 15: Bodoče možnosti pokrajin (Palang, Printsmann, Alumäe, Kaur, 0ja, Prede, Pungas, Reimann, Sooväli 2003). Glej angleški del prispevka.

Antrop (1998) pravi, da so pokrajine dinamičen pojav, saj se neprestano spreminjajo. Gibalo vsega razvoja je globalizacija kot vseobsežna in večplastna sila (Ogrin 1999). Antrop (2002) k seznamu gonilnih sil, ki vplivajo na pokrajinske spremembe, prišteva tudi dostopnost, urbanizacijo in nesreče. Največja grožnja za pokrajine Srednje in Vzhodne Evrope sta opuščanje gospodarske rabe na eni strani in pretirana raba na drugi strani, globalno gledano marginalizacija in intenzifikacija - oboje izničuje plastovito dediščino pokrajin. Nekdaj zaprta območja so na stežaj odprla svoja vrata. Mestno življenje zamenjuje nekdanje podeželsko. Globalizacija uniformira podobo in funkcije pokrajine. Lahko sicer sprožimo spremembe v pokrajini, ampak obenem moramo zaščititi njene lokalne značilnosti (slika 15). Lahko poskušamo vpeljati globalne značilnosti, ampak še vedno si moramo prizadevati ohraniti tradicionalni videz. Najslabši možni scenarij bi pripeljal do moderne pokrajine z globalnimi lastnostmi (igrišča za golf, na primer) (Palang, Printsmann, Alumäe, Kaur, Oja, Prede, Pungas, Reimann, Sooväli 2003). Torej načrtovanje in uvajanje novih dejavnosti (zabaviščnih in prostočasnih) in ohranjanje starih skoraj nujno povzročita napetosti in nestrinjanje med strokovnjaki in širšo javnostjo.

Slika 16: Kulturna pokrajina kot palimpsest (Vervloet 1986). Nekatere pokrajinske prvine so ostale nespremenjene kljub številnim družbeno-ekonomskim spremembam. Nekatere druge so utonile v pozabo ali bile ob nastanku novih ureditev uničene. Spet tretje so zamenjale nove. Nekatere druge so ohranile fizično zgradbo, vendar se je njihov pomen spremenil. Pokrajina je torej zbirka ostankov vseh ureditev, iz katerih se dajo razbrati »0dlomki« različnih časovnih obdobij.

Glej angleški del prispevka. 
Eno od možnih rešitev, kako preseči odtujitev, ponuja pokrajina sama kot palimpsest (slika 16). Kar je vredno, se bo ohranilo, kar ni, bo izginilo. Vendar se tudi vrednostni sistem spreminja. Nekatere prvine pokrajine, ki so bile cenjene v času monarhij, so bile v komunističnem/socialističnem času popolnoma prezrte. Ponovno so pridobile vrednost z osamosvojitvijo oziroma s padcem diktature (Alumäe, Printsmann, Palang 2003; Stenseke 1999). Vse do 20. stoletja je šel razvoj izginevanja/ohranjanja kulturnih prvin po naravni poti, potem pa smo začeli ohranjevati, varovati prvine in pokrajine per se (več glej Gustavsson in Peterson 2003). Ohranjene vidne prvine pokrajine lahko dobijo nov pomen v novih ureditvah in za prihodnje generacije. V tem kontekstu je tudi v srednje- in vzhodnoevropskih državah pokrajina pojmovana kot dediščina: je shramba materialnih ostankov, zato otipljiva, in je torej najstabilnejši pojav v našem okolju. Cenimo prispevek naših prednikov k razvoju pokrajine, ki ustvarja čut pripadnosti. Za razumevanje pokrajin moramo najprej razumeti njihove zgodovinske sloje in množico pomenov, ki jih posamična pokrajinska prvina ima, prav tako pa tudi procese, ki potekajo $\mathrm{v}$ pokrajinah. To spoznanje še ni prišlo v zavest oziroma vsakodnevno prakso, ker v vsakdanjem jeziku izraz pokrajina še nima časovne dimenzije. Spremembe in njihovo obvladovanje zahtevajo svoj čas, da se umestijo tako v pokrajino kot tudi v jezik.

Zavedanje o pomembnosti pokrajine se krepi, še posebej ob upoštevanju, da je pomemben dejavnik kakovosti življenja tako posameznika kot tudi celotne lokalne skupnosti. Pokrajina pomembno oblikuje človekovo mišljenje, ideje, čustva in identiteto. Tudi danes ljudje čutijo potrebo po pripadanju pokrajini in posedovanju svojega mesta v njej. Pokrajina pomeni ljudem vir življenja in je rezultat njihovega lastnega dela. Ljudje pričakujejo, da je pokrajina del njihovega življenja in sebe imajo za del pokrajine.

\section{Sklep}

Članek govori o tem, kako so družbeno-ekonomske spremembe v Srednji in Vzhodni Evropi v 20. stoletju povzročile odtujitev ljudi od pokrajin, in sicer zato, ker so bili preobrati tako hitri, da ljudje niso mogli dojeti sprememb, kaj šele, da bi jih ponotranjili. Prepad je bil tako globok, da ljudje v večini primerov niso mogli dojeti vsebine prejšnjih ureditev; na drugi strani pa so bili sloji tako tanki, da večina novonastalih pokrajin ni imela časa, da bi postala del vsakdanjega življenja. To še posebej velja za duhovno razsežnost pokrajin, ki normalno zahteva dlje časa, da postane sestavni del tradicije, ko pa je enkrat zakoreninjena, jo lahko izruva le revolucionarni preobrat ali počasen in dolgotrajen proces. Celotno 20. stoletje, še posebej njegova druga polovica, je bilo razburkano obdobje. Politično motivirane družbene in ekonomske spremembe je spremljal organski razvoj, ki so ga povzročili urbanizacija, globalizacije in drugi družbeni procesi. Oblike, funkcije in pomeni pokrajin so nagnjeni k spremembam, ki jih prinaša čas. To je razlog, da so spremembe raznolike in jih je zato težko razumeti in sprejeti.

Najpomembnejše je, da se ljudje identificirajo z novimi pomeni pokrajine in s tem razvijejo odgovoren odnos do nje. Cut pripadnosti pokrajini, ki ima kulturno in zgodovinsko vrednost ter je življenjski prostor družinskih članov in članov lokalne skupnosti, je zagotovilo, da se bo skrbi za lastno dobro pridružila še skrb za pokrajino. Da bi se ljudje navezali na svoje pokrajine, so potrebni preudarni in dolgoročno usmerjeni ukrepi na lokalni, državni in vseevropski ravni ob hkratnem ustreznem vrednotenju naravnih in družbenih prvin in njihovem vključevanju v izvedljive razvojne programe. Le razumne poteze, ki bodo upoštevale družbene in ekonomske razmere lokalnega prebivalstva, bodo omogočile uravnotežen razvoj pokrajin in zagotovile njihovo stabilnost.

\section{Zahvala}

Estonski del študije je financirala Estonska znanstvena fundacija, dotacija št. 4589, in Finska akademija, raziskovalni program št. 105304 - Transboundary landscapes.

\section{Literatura}

Glej angleški del prispevka. 